\title{
Drivers of Sediment Accumulation and Nutrient Burial in Coastal Stormwater Detention Ponds, South Carolina, USA
}

\author{
William F. Schroer, ${ }^{1,4 *}$ Claudia R. Benitez-Nelson, ${ }^{1}$ Erik M. Smith,,${ }^{1,2,3}$ and \\ Lori A. Ziolkowski ${ }^{1}$
}

\begin{abstract}
${ }^{1}$ School of the Earth, Ocean, and Environment, University of South Carolina, Columbia, South Carolina 29208, USA; ${ }^{2}$ Belle W. Baruch Institute for Marine and Coastal Sciences, University of South Carolina, Columbia, South Carolina 29208, USA; ${ }^{3}$ North Inlet-Winyah Bay National Estuarine Research Reserve, Georgetown, South Carolina 29442, USA; ${ }^{4}$ Present address: Department of Marine Sciences, University of Georgia, Athens, Georgia 30602, USA
\end{abstract}

\begin{abstract}
Stormwater detention ponds are widely utilized as control structures to manage runoff during storm events. These ponds also represent biogeochemical hotspots, where carbon $(\mathrm{C})$ and nutrients can be processed and buried in sediments. This study quantified $\mathrm{C}$ and nutrient [nitrogen $(\mathrm{N})$ and phosphorus (P)] sources and burial rates in 14 stormwater detention ponds representative of typical residential development in coastal South Carolina. Bulk sediment accumulation was directly correlated with catchment impervious surface
\end{abstract}

Received 28 July 2017; accepted 11 November 2017;

published online 16 January 2018

Electronic supplementary material: The online version of this article (https://doi.org/10.1007/s10021-017-0207-z) contains supplementary material, which is available to authorized users.

Authors' Contribution: EMS and CBN were responsible for the original conception and design of this study, with input from WFS and LAZ. Sample collection and bathymetric mapping were performed by WFS. Phosphorus analyses were performed by WFS with assistance from CBN. Carbon and nitrogen analyses were performed by WFS with assistance from EMS. $N$-alkane analyses were performed by WFS with assistance from LAZ. WFS, CBN, EMS, and LAZ were responsible for data interpretation. WFS drafted the manuscript and all authors contributed critical revisions.

*Corresponding author; e-mail: William.Schroer@uga.edu coverage $\left(R^{2}=0.90\right)$ with sediment accumulation rates ranging from 0.06 to $0.50 \mathrm{~cm} \mathrm{y}^{-1}$. These rates of sediment accumulation and consequent pond volume loss were lower than anticipated based on maintenance guidelines provided by the State. $\mathrm{N}$ alkanes were used as biomarkers of sediment source; the derived terrestrial aquatic ratio $\left(\mathrm{TAR}_{\mathrm{HC}}\right)$ index was strongly correlated with sediment accumulation rate $\left(R^{2}=0.71\right)$ which, in conjunction with high $\mathrm{C} / \mathrm{N}$ ratios (16-33), suggests that terrestrial biomass drives this sediment accumulation, with relatively minimal contributions from algal derived material. This is counter to expectations that were based on the high algal productivity generally observed in stormwater ponds and previous studies of natural lakes. Sediment $\mathrm{C}$ and nutrient concentrations were consistent among ponds, such that differences in burial rates were a simple function of bulk sediment accumulation rate. These burial rates $\left(\mathrm{C}: 8.7-161 \mathrm{~g} \mathrm{~m}^{-2} \mathrm{y}^{-1}, \mathrm{~N}\right.$ : $0.65-6.4 \mathrm{~g} \mathrm{~m}^{-2} \mathrm{y}^{-1}, \quad$ P: $\quad 0.238-4.13 \mathrm{~g} \mathrm{~m}^{-2} \mathrm{y}^{-1}$ ) were similar to those observed in natural lake systems, but lower than those observed in reservoirs or impoundments. Though individual ponds were small in area $\left(930-41,000 \mathrm{~m}^{2}\right)$, they are regionally abundant and, when mean burial rates are extrapolated to the regional scale $(\approx 21,000$ ponds), ultimately sequester $2.0 \times 10^{9} \mathrm{~g} \mathrm{C} \mathrm{y}^{-1}$, 
$9.5 \times 10^{7} \mathrm{~g} \mathrm{~N} \mathrm{y}^{-1}$, and $3.7 \times 10^{7} \mathrm{~g} \mathrm{P} \mathrm{y}^{-1}$ in the coastal region of South Carolina alone. Stormwater ponds represent a relatively new but increasingly significant feature of the coastal landscape and, thus, are a key component in understanding how urbanization alters the transport and transforma- tions of $\mathrm{C}$ and nutrients between terrestrial uplands and downstream receiving waters.

Key words: stormwater pond; sediment; carbon; nitrogen; phosphorus; $n$-alkane; impervious surfaces; terrestrial biomass; algal biomass; burial.

\section{HighLIGHTS}

- Stormwater ponds are regionally abundant, sequester $\mathrm{C}, \mathrm{N}$ and $\mathrm{P}$ at rates comparable to natural lakes

- Terrestrial, not algal, biomass is the dominant source of organic matter to sediments

- Sediment accumulation as well as $\mathrm{C}, \mathrm{N}$ and $\mathrm{P}$ sequestration are driven by impervious surface coverage

\section{INTRODUCTION}

Global population growth and urbanization has led to a myriad of environmental impacts, key among them being modification of global biogeochemical cycles (Vitousek and others 1997). Contributing to this modification are the landscape alterations associated with the expansion of urban and suburban population centers, vehicle emissions, fertilizer use on lawns, industrial release of nutrient pollutants, and municipal waste management effluent (Fissore and others 2011). One of the most striking of these landscape changes is the rise in impervious surfaces, which is often associated with a variety of impacts to downstream receiving waters (Holland and others 2004). Impervious surfaces, such as roads, parking lots, and buildings, restructure urban hydrology by increasing the volume and velocity of runoff water during storm events, which can amplify flood risk, erosion, and pollutant transport (Corbett and others 1997a; Grimm and others 2008; Jacobson 2011). Furthermore, impervious surfaces displace vegetated surfaces capable of fixing carbon (C) and storing nutrient pollutants in biomass and soils.

To mitigate the impacts of impervious surfaces, most new urban and suburban development is required to meet increasingly stringent stormwater control measures through use of structural control measures or other landscape features that intercept runoff water and mediate release to receiving waters (Verstraeten and Poesen 2000). In many regions, stormwater detention ponds serve as the most commonly employed stormwater structural control measure (Tixier and others 2011). Though no limnologic distinction between ponds and lakes exists, stormwater ponds are generally smaller than $20,000 \mathrm{~m}^{2}$ and are shallow, which allows for widespread light penetration to the benthos (Biggs and others 2005; Søndergaard and others 2005). Stormwater ponds, further exhibit great morphometric diversity with variable surface areas, depth, and configuration (Chiandet and Xenopoulos 2011). In many regions, ponds represent new wildlife habitats and are colonized by aquatic plants, fish, amphibians, and waterfowl (Bishop and others 2000). In the southeastern USA in particular, ponds have added aesthetic value resulting in increased property values (Bastien and others 2012).

The South Carolina coastal plain is representative of many coastal regions that are currently experiencing rapid rates of growth. Widespread urban and suburban expansion has led to a boom in the construction of stormwater ponds. There are now more than 21,000 constructed ponds in the eight coastal counties of South Carolina alone (E. Smith, unpublished data), a region where historically there were essentially no natural ponds or other lentic ecosystems. These created ponds are integrated into the ecosystem, receiving inputs of suspended particulate matter and dissolved nutrients in runoff. Over time, suspended particulate matter sinks and accumulates as sediment. The net accumulation of sediment in stormwater ponds is environmentally significant for two reasons. First, the accumulation of sediment displaces water volume, thus reducing the designed water quantity and quality management function of these ponds. South Carolina state regulations in fact require that stormwater ponds be dredged when sediment accumulation displaces $25 \%$ of the ponds' storage volume, which is assumed to occur every 510 years (SCDHEC 2005). This dredging can impose substantial financial burdens on property owners (Brainard and Fairchild 2012; Cotti-Rausch and DeVoe 2017). 
Second, small waterbodies have been identified as hotspots of biogeochemical activity and environmental pollutant exposure, with sediments being a key site of $\mathrm{C}$ and nutrient reprocessing and burial (Stanley 1996; Wu and others 1996; Comings and others 2000; Mallin and others 2002; Downing 2010; Weinstein and others 2010; Cheng and Basu 2017). Indeed, there is growing interest in the role that inland waters, including so-called artificial water bodies, play in global C cycling (Cole and others 2007; Tranvik and others 2009). Though lakes account for only $1 \%$ of the earth's surface area, conservative estimates predict that lakes and reservoirs bury $0.23 \mathrm{Pg} \mathrm{C} \mathrm{Y}^{-1}$, a rate comparable to global C burial in ocean sediments (Cole and others 2007). In the continental USA, small artificial water bodies are estimated to account for $20 \%$ of total surface water and have disproportionately high rates of C sequestration (Smith and others 2002; Downing and others 2006; Cole and others 2007; Downing and others 2008; Tranvik and others 2009). These high rates of organic $C$ burial are hypothesized to be the result of increased internal production and deposition of algal biomass (Downing and others 2008; Anderson and others 2014; Clow and others 2015). Stormwater ponds, as small, often eutrophic waterbodies (Siegel and others 2011), are hypothesized to follow this trend (Lewitus and others 2008), though they are also exposed to external sources of terrestrial biomass such as leaves and grass clippings (Grimm and others 2008).

In addition to their role in $\mathrm{C}$ cycling, small water bodies may also act as nutrient traps, though variable efficiencies have been reported (Comings and others 2000; Mallin and others 2002; Gold and others 2017). In lentic systems, nitrogen (N) removal is dominated by three processes: denitrification, nitrogen fixation, and organic matter burial (Saunders and Kalff 2001; Harrison and others 2009; Gold and others 2017). The dominant process by which phosphorus $(\mathrm{P})$ is removed by lentic systems, however, is sediment burial. The particle reactive nature of inorganic $\mathrm{P}$ results in the sedimentation of particle adhered inorganic $\mathrm{P}$ as well as organically bound P (Søndergaard and others 2003). In sediment, inorganic $P$ may be retained by forming complexes with a variety of substrates that may be redox and pH dependent (Jacoby and others 1982; Søndergaard and others 2003; Kopáček and others 2005). P can also be fixed into autotroph biomass, which may ultimately by buried, exported, or remineralized (Søndergaard and others 2003).
Stormwater ponds are created within altered urban landscapes. Though there has been extensive research into the impacts of urbanization on the biogeochemical cycles of lotic systems (Walsh and others 2005,2012; Booth and others 2016), urban ponds have not received the same level of attention. There is still only a limited understanding of the role stormwater ponds play in urban biogeochemical cycles (Williams and others 2013; Chiandet and Xenopoulos 2016; Cheng and Basu 2017). This is especially true in coastal urban centers where stormwater runoff and pond discharges directly enter estuarine and marine receiving waters. As ponds are poor sites of denitrification they are generally more effective sinks of particle reactive P (Comings and others 2000; Moore and Hunt 2012; Gold and others 2017).

The goal of the present study was to quantify the rates of $\mathrm{C}$ and nutrient sequestration within stormwater pond sediments as well as identify the morphometric and landscape factors that drive this sequestration. To date few studies have specifically focused on the role of stormwater pond sediments or sedimentation processes in urban pond biogeochemistry. These findings will ultimately allow for comparison of the biogeochemical function between stormwater ponds and other lentic systems both natural and engineered. In the process, we identify the dominant sources of organic matter to sediments, determining the fate of algal biomass produced within ponds, as well as quantify rates of bulk sediment accumulation. In addition to furthering an understanding of how urban stormwater management impacts landscape-scale organic matter transport and transformations, this study will have direct implications for future management and regulatory decisions regarding pond function, performance, and maintenance practices.

\section{METHODS}

\section{Study Sites}

This study examined fourteen stormwater wet detention ponds from the coastal region of South Carolina (USA) (Figure 1). All ponds were located in residential urban and suburban communities within Georgetown and Horry Counties. The ponds were selected to represent a wide range catchment development density (Table 1).

The percentage of pond catchment covered by impervious surface (\%Ip) was calculated for each community. Impervious surfaces were defined as any paved surface (roads, driveways, sidewalks, 


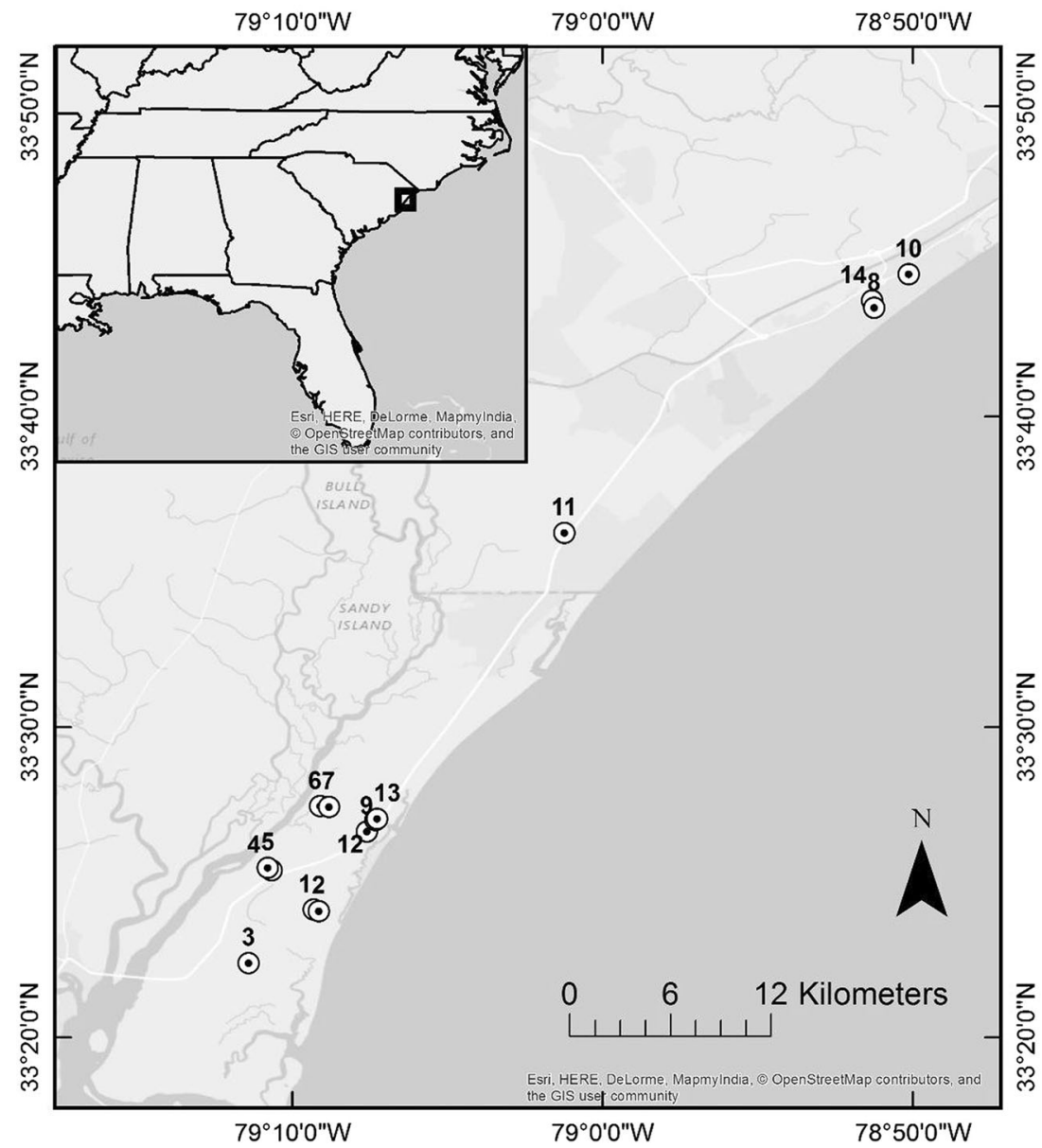

Figure 1. Map of sample pond locations. Circles denote pond location and are labeled with Pond ID. Inset shows geographic location of ponds in the Southeastern USA

Table 1. General Characteristics of Sample Ponds

\begin{tabular}{|c|c|c|c|c|c|c|c|}
\hline Pond ID & Latitude (N) & Longitude (W) & Year built & Month sampled (2016) & $\%$ Ip & Pond SA $\left(\mathrm{m}^{2}\right)$ & Pond Perimeter (m) \\
\hline 1 & $33^{\circ} 24^{\prime} 04^{\prime \prime}$ & $79^{\circ} 0908^{\prime \prime}$ & 1996 & July & 7 & 2850 & 250 \\
\hline 2 & $33^{\circ} 24^{\prime} 07^{\prime \prime}$ & $79^{\circ} 19^{\prime} 09^{\prime \prime}$ & 1996 & July & 7 & 3810 & 280 \\
\hline 3 & $33^{\circ} 22^{\prime} 25^{\prime \prime}$ & $79^{\circ} 11^{\prime} 29^{\prime \prime}$ & 1996 & March & 14 & 40,560 & 2500 \\
\hline 4 & $33^{\circ} 25^{\prime} 34^{\prime \prime}$ & $79^{\circ} 10^{\prime} 41^{\prime \prime}$ & 2004 & March & 26 & 6380 & 530 \\
\hline 5 & $33^{\circ} 25^{\prime} 28^{\prime \prime}$ & $79^{\circ} 10^{\prime} 47^{\prime \prime}$ & 2004 & March & 26 & 11,290 & 590 \\
\hline 6 & $33^{\circ} 27^{\prime} 27^{\prime \prime}$ & $79^{\circ} 09^{\prime} 06^{\prime \prime}$ & 1994 & May & 28 & 1020 & 180 \\
\hline 7 & $33^{\circ} 27^{\prime} 26^{\prime \prime}$ & $79^{\circ} 08^{\prime} 49^{\prime \prime}$ & 1994 & March & 29 & 930 & 170 \\
\hline 8 & $33^{\circ} 43^{\prime} 30^{\prime \prime}$ & $78^{\circ} 51^{\prime} 15^{\prime \prime}$ & 1977 & March & 31 & 2570 & 290 \\
\hline 9 & $33^{\circ} 26^{\prime} 39^{\prime \prime}$ & $79^{\circ} 07^{\prime} 36^{\prime \prime}$ & 2002 & March & 39 & 3560 & 290 \\
\hline 10 & $33^{\circ} 44^{\prime} 35^{\prime \prime}$ & $78^{\circ} 50^{\prime} 08^{\prime \prime}$ & 1973 & May & 42 & 1380 & 200 \\
\hline 11 & $33^{\circ} 36^{\prime} 15^{\prime \prime}$ & $79^{\circ} 01^{\prime} 14^{\prime \prime}$ & 2009 & Sept & 44 & 1690 & 190 \\
\hline 12 & $33^{\circ} 27^{\prime} 01^{\prime \prime}$ & $79^{\circ} 07^{\prime} 19^{\prime \prime}$ & 1998 & July & 48 & 1330 & 180 \\
\hline 13 & $33^{\circ} 27^{\prime} 03^{\prime \prime}$ & $79^{\circ} 07^{\prime} 17^{\prime \prime}$ & 1998 & July & 48 & 2360 & 260 \\
\hline 14 & $33^{\circ} 43^{\prime} 44^{\prime \prime}$ & $78^{\circ} 51^{\prime} 29^{\prime \prime}$ & 1992 & March & 51 & 930 & 170 \\
\hline
\end{tabular}


and so on) or building (Chiandet and Xenopoulos 2011; Jacobson 2011). The polygon tool in Google Earth Professional (available in free Google Earth Desktop App) was utilized to delineate pond catchment area (CA), pond surface area (SA), and the total area of impervious surface.

Residential communities are engineered in such a way that all stormwater runoff is directed toward the detention pond. Thus, in communities with clear boundaries and generally higher development density, the pond catchment was defined as the community perimeter, number of ponds $(n)=7$. In large multi-pond communities, the pattern of development generally consists of a ring road that runs along the perimeter of each pond with houses built on both sides of this road (pond front and non-pond front). These communities were often too large to make a clear delineation of drainage area feasible. The catchment for these ponds was drawn so as to encompass the ring road and nonpond front houses $(n=3)$. For ponds in urban residential areas not associated with a discrete community, the catchment was defined as an approximate two-block ( $200-250 \mathrm{~m}$ ) radius from the pond $(n=2)$. The blocks surrounding these ponds were largely homogenous with respect to impervious surface coverage, so altering this radius did not change \% Ip beyond the margin of error. For ponds from more forested communities, the catchment was drawn to include all structures and lawns surrounding the pond plus $\sim 25 \mathrm{~m}$ of surrounding forest $(n=2)$. The lack of topographic slope in the area makes it difficult to delineate a specific catchment; we argue that it is unlikely that surface runoff reaches these ponds from far within the tree line.

The area of impervious surface was found by tracing the outline of all impervious surfaces as defined using the Google Earth polygon tool. Impervious surfaces were delineated at a map scale of about 1:1000. SA was also delineated using the Google Earth polygon tool coupled with satellite imagery of pond surface. Our observations of stormwater ponds showed that water level fluctuations through time were minimal and result in negligible changes to pond SA.

Percent impervious surface coverage (\%Ip) was calculated by the following equation:

$$
\% \text { Ip }=\frac{A_{\text {Ip }}}{\text { CA }- \text { SA }}
$$

where $A_{\text {Ip }}$ was the area of impervious surface, CA was the catchment area, and SA was the pond surface area. To determine the error associated with $\%$ Ip, the catchments and ponds of five communities and impervious surfaces of three communities were delineated in triplicate. The mean residual errors for ponds SA, catchment, and total impervious were propagated through the \% Ip equation (above). This method yielded a $5.1 \%$ error-associated \%Ip.

\section{Sediment Thickness and Bathymetry}

A bathymetric survey of each pond was conducted using a small john boat with an OHMEX system, SonarMite V3 Echosounder and Trimble R8 GNSS. Depth readings were taken at $1.0-\mathrm{m}$ intervals as the vessel traversed a path of concentric circles from pond bank to center followed by several crosshatching transects. Sediment thickness was determined by a survey of $8-46$ cores per pond. Sediment thickness survey cores were collected from a series of transects, where possible, or evenly distributed when features such as pond aeration fountains or unusual basin morphology made transects less feasible. Cores were collected using a push corer with a $6.67 \mathrm{~cm}$ diameter by $60-\mathrm{cm}$-long polycarbonate liner. Sample locations were recorded using the Trimble R8 GNSS. Sediment thickness was determined by visually inspecting the core and measuring the sediment height above a visually evident interface between a darker silt and lighter colored sand. The dark, silty sediments above this interface were assumed to be accumulated stormwater pond sediments. The light colored sandy layer below the interface was assumed to be the native soil into which the pond was dug. In the field, measurements of the accumulated layer thickness were taken twice for each core, at opposite sides of the polycarbonate liner; the mean was recorded as the sediment thickness for that sample location.

ARC GIS 10.2.2 software was used to generate pond bathymetries and sediment thickness maps. Pond bathymetries were interpolated by kriging within the pond's perimeter (as defined using satellite imagery) $(n=7)$. Sediment thickness maps were initially interpolated using kriging; however, the variability of sediment thickness or "patchiness" in some ponds resulted in significant errors. In these ponds, inverse distance weighting was used to interpolate sediment thickness. Interpolated bathymetry and sediment thickness surfaces were integrated to calculate total pond volume and total sediment volume. Sediment accumulation rates for each pond were then calculated as:

$$
\text { Accumulation rate }=\frac{V_{\text {sed }}}{\mathrm{SA} \times \mathrm{y}}
$$


where $V_{\text {sed }}$ was the volume of sediment $\left(\mathrm{m}^{3}\right)$, SA was pond surface area $\left(\mathrm{m}^{2}\right)$, and $y$ was the age of the pond (years). Pond age was determined by reviewing real estate records in conjunction with historical aerial and satellite imagery. During the development of a community, ponds are dug immediately prior to the construction of houses. As a result, the age of the oldest house in a community provided a reasonable estimate of pond age, to within a year. The error associated with sediment volume was determined by cross-validation of the interpolation model (kriging or IDW); mean standardized error was converted to percent error, which was applied to sediment volume. Model errors for each pond ranged from 0.6 to $12 \%$, ponds with more even gradients of sediment distribution exhibited lower model error. $S A$ error was determined to be $2.7 \%$ by re-delineating a subsample of 4 ponds in triplicate. The accumulation rate error was subsequently determined by propagating the component errors. Pond volume loss was calculated as:

$$
\text { volume loss }(\%)=\frac{V_{\text {sed }}}{V_{\text {pond }}+V_{\text {sed }}} \times 100
$$

where $V_{\text {sed }}$ was the volume of sediment $\left(\mathrm{m}^{3}\right)$ and $V_{\text {pond }}$ was the bathymetric volume or volume of water stored at time of measurement $\left(\mathrm{m}^{3}\right)$. As stated earlier, ponds in this study tend to maintain a constant water level.

\section{Sample Collection for Biogeochemical Analyses}

Five to eight sediment cores for biogeochemical analyses were collected from each pond using the push corer described above. Core collection sites varied with pond morphology and included locations at influent points, effluent points, littoral regions, basin centers, and any sub-basins. All cores reached the layer of native soil and were recovered with a clear sediment water interface. Cores were extruded and sliced into $1 \mathrm{~cm}$ sections using an incremental core extruder and weighed to determine bulk wet mass $(\mathrm{g})$. All samples were frozen at $-20^{\circ} \mathrm{C}$ until laboratory analysis. From each pond, three cores were selected for $\mathrm{C}, \mathrm{N}$, and $\mathrm{P}$ analyses, of which, two cores were selected for biomarker analyses. Cores were selected to represent spatial variability within the pond. A subsample of each core section was weighed, freeze-dried, and subsequently reweighed. Subsamples were then homogenized by mortar and pestle.

\section{Carbon and Nutrient Analyses}

Particulate $\mathrm{C}$ and particulate $\mathrm{N}$ were analyzed simultaneously with a Costech ECS 4010 Elemental Analyzer. Samples were run with an atropine standard curve (Costech \#031042; 70.56\%C, $4.84 \% \mathrm{~N}$ ), alongside standard reference material (NIST RM 8704, buffalo river sediment) about 8\% of samples was run in duplicate with a mean coefficient of variability of $0.0469 \pm 0.0227$ (SD) for $\mathrm{C}$ and $0.0520 \pm 0.0229$ for $\mathrm{N}$. To test the assumption that total $\mathrm{C}$ represented organic $\mathrm{C}$ in pond sediments, inorganic $\mathrm{C}$ was analyzed by two methods in 15 samples. The first method was a digestion with $10 \% \mathrm{HCl}$ for $12 \mathrm{~h}$ to remove inorganic $\mathrm{C}$ prior to $\mathrm{C}$ and $\mathrm{N}$ analysis. The second was pre-combusted at $500^{\circ} \mathrm{C}$ for $4.5 \mathrm{~h}$ to remove organic $\mathrm{C}$ prior to $\mathrm{C}$ and $\mathrm{N}$ analysis. No detectable inorganic $\mathrm{C}$ was measured, supporting the assumption that total $\mathrm{C}$ represents organic $\mathrm{C}$.

Total particulate $\mathrm{P}$ (TPP) and particulate inorganic P (PIP) were analyzed using an ash/hydrolysis assay described in Aspila and others (1976) as modified by Benitez-Nelson and others (2007). Particulate organic P (POP) was calculated as the difference between TPP and PIP. Samples were run alongside standard reference materials (NIST 1646a, estuarine sediment and NIST 1515, tomato leaves), and approximately $15 \%$ of samples were run in duplicate with an average coefficient of variability of $0.0976 \pm 0.0336$.

Sediment concentrations of $\mathrm{C}, \mathrm{N}$, and $\mathrm{P}$ were calculated as \% of dry weight, and the molar ratios $\mathrm{C} / \mathrm{P}, \mathrm{C} / \mathrm{N}$, and $\mathrm{N} / \mathrm{P}$ were determined within each $1 \mathrm{~cm}$ section. Core $\mathrm{C}, \mathrm{N}$, and $\mathrm{P}$ concentrations and ratios were then calculated as the mean of all sections in that core. Pond sediment $\mathrm{C}, \mathrm{N}$, and $\mathrm{P}$ concentration and ratios were calculated as the mean of all core concentrations from that pond. This method of calculation was used to prevent biasing pond values toward longer cores.

\section{Biomarkers}

From each pond, the surface sediments of two cores were selected for biomarker analysis. The biomarker values reported for each pond represent the mean of these two samples, and errors represent their range. For alkane extractions, $0.5-2 \mathrm{~g}$ of freeze-dried and homogenized sediment was sonicated in $50 \mathrm{ml}$ of a 9:1 DCM/MeOH solution for $30 \mathrm{~min}$ and filtered through a Whatman glass fiber filter. Each sample was sonicated three separate times using fresh $50 \mathrm{ml}$ 9:1 DCM/MeOH for a total of $150 \mathrm{ml}$. The samples were subsequently dried 
down to $\sim 5 \mathrm{ml}$ under a stream of ultra-high purity (UHP) $\mathrm{N}_{2}$ and treated overnight with about $2 \mathrm{~g}$ of activated copper to remove sulfur. Samples were then dried and re-dissolved in $1 \mathrm{ml}$ of hexane. Silica gel column chromatography (4 g activated silica gel with $40 \mathrm{ml}$ hexane as mobile phase) was used to isolate alkanes. Samples were then dried down to $1 \mathrm{ml}$ prior to GC-MS analysis.

Alkanes were quantified using an Agilent 7890B/ 5977A GC/MS, with an HP-5MS column, using He as a carrier gas, and a temperature program that began at $100^{\circ} \mathrm{C}$, ramped up $8^{\circ} \mathrm{C} \mathrm{min}^{-1}$ to $300^{\circ} \mathrm{C}$, then held isothermal for $23 \mathrm{~min}$. Scanning ion monitoring (SIM), detecting ion $\mathrm{m} / \mathrm{z}$ of 71 , was used for the identification of $n$-alkanes. Quantification was completed using external standards $(n$ alkane standards $\mathrm{C}_{18}, \mathrm{C}_{20}, \mathrm{C}_{24}, \mathrm{C}_{26}$, and $\mathrm{C}_{30}$ ). Laboratory blanks were analyzed with each sample set to assess contamination.

$\mathrm{N}$-alkanes are a stable group of lipids biosynthesized by aquatic and terrestrial primary producers. Long chain length $n$-alkanes $\left(>\mathrm{C}_{21}\right.$ ) are associated with the epicuticular leaf waxes of vascular plants (Eglinton and Hamilton 1967). Shorter chain length $n$-alkanes, notably $\mathrm{C}_{15}, \mathrm{C}_{17}$, and $\mathrm{C}_{19}$, are associated with algal biomass production (Meyers 2003). There is a great deal of error inherent in direct comparisons of $n$-alkane concentration (either as $\mu \mathrm{g} \mathrm{g}^{-1}$ sediment or as $\mu \mathrm{g} \mathrm{g}^{-1} \mathrm{OC}$ ) because the percent recovery achieved by laboratory methods is unknown and may differ among samples and runs. To minimize this error, biomarker results are often expressed as a unitless ratio. Two proxy indices were applied in this project for their ability to discriminate among algal, terrestrial, and aquatic macrophyte signatures. The terrestrial aquatic ratio $\left(\mathrm{TAR}_{\mathrm{HC}}\right)$ shows the magnitude of terrestrial signals relative to algal material. The $\mathrm{TAR}_{\mathrm{HC}}$ is calculated as the ratio from mass (Bourbonniere and Meyers 1996):

$$
\mathrm{TAR}_{\mathrm{HC}}=\frac{\mathrm{C}_{27}+\mathrm{C}_{29}+\mathrm{C}_{31}}{\mathrm{C}_{15}+\mathrm{C}_{17}+\mathrm{C}_{19}}
$$

In this study, however, the $\mathrm{C}_{15}$ alkane signal in our samples was often below the limit of detection. Thus, we used a modified $\mathrm{TAR}_{\mathrm{HC}}$ as described by van Dongen and others (2008), where:

$$
\mathrm{TAR}_{\mathrm{HC}}=\frac{\mathrm{C}_{27}+\mathrm{C}_{29}+\mathrm{C}_{31}}{\mathrm{C}_{17}+\mathrm{C}_{19}}
$$

The portion aquatic $\left(\mathrm{P}_{\mathrm{aq}}\right)$ index delineates the relative signatures of aquatic macrophyte biomass versus terrestrial biomass. $\mathrm{P}_{\mathrm{aq}}$ is calculated as the ratio from mass (Ficken and others 2000):

$$
P_{a q}=\frac{C_{23}+C_{25}}{C_{23}+C_{25}+C_{29}+C_{31}}
$$

\section{Data Analysis}

Linear correlations were used to determine relationships between independent and dependent variables including \%Ip, sediment accumulation, nutrient burial, biomarkers. Linear regressions were also used to determine down core trends of nutrient concentrations in sediment depth profiles. Single sample $t$ tests were used to determine general trends from nutrient profile regression data, testing the null hypothesis that the regression slope $=0$ for all cores within a sample population. A matched pairs $t$ test was used to compare the difference in magnitude between nutrient depth profile regression slopes.

\section{RESUlts \\ Sediment Accumulation and Dry Bulk Density}

Sediment thickness was highly variable within each pond generally spanning 1-2 orders of magnitude. Interpolated maps of sediment thickness, however, allowed for a mean sediment thickness to be determined in ponds with variable sediment thickness and accumulation patterns. Some ponds exhibited an even gradient of sedimentation radiating from pond influent points (Figure 2A), whereas others exhibited a patchy pattern of accumulation, not necessarily reflective of pond morphology (Figure 2B). Mean sediment thickness varied among ponds and ranged from $1.2 \pm 0.1$ to $20.5 \pm 0.8 \mathrm{~cm}$. Using the sediment volume and bathymetric volumes calculated from interpolation models, we found that pond volume loss ranged from $1.0 \pm 0.2$ to $17.5 \pm 0.5 \%$ (Table 2). Sediment accumulation rates ranged from $0.06 \pm 0.01$ to $0.50 \pm 0.03 \mathrm{~cm} \mathrm{y}^{-1}$ with a mean accumulation rate across all ponds of $0.32 \pm 0.15 \mathrm{~cm} \mathrm{y}^{-1}$ (Table 2). Sediment accumulation rate was directly correlated with catchment \%Ip $\left(R^{2}=0.90\right.$, Figure 3), SA, and the SA/CA ratio (Table 2). There was no relationship between sediment accumulation rate and volume loss or pond age. Sediment bulk density varied with a range of 0.14 $0.51 \mathrm{~g} \mathrm{~cm}^{-3}$ and a mean of $0.32 \pm 0.09 \mathrm{~g} \mathrm{~cm}^{-3}$ (Table 2). Bulk density was not significantly correlated with accumulation rate or with any morphometric characteristics (Table 3). 

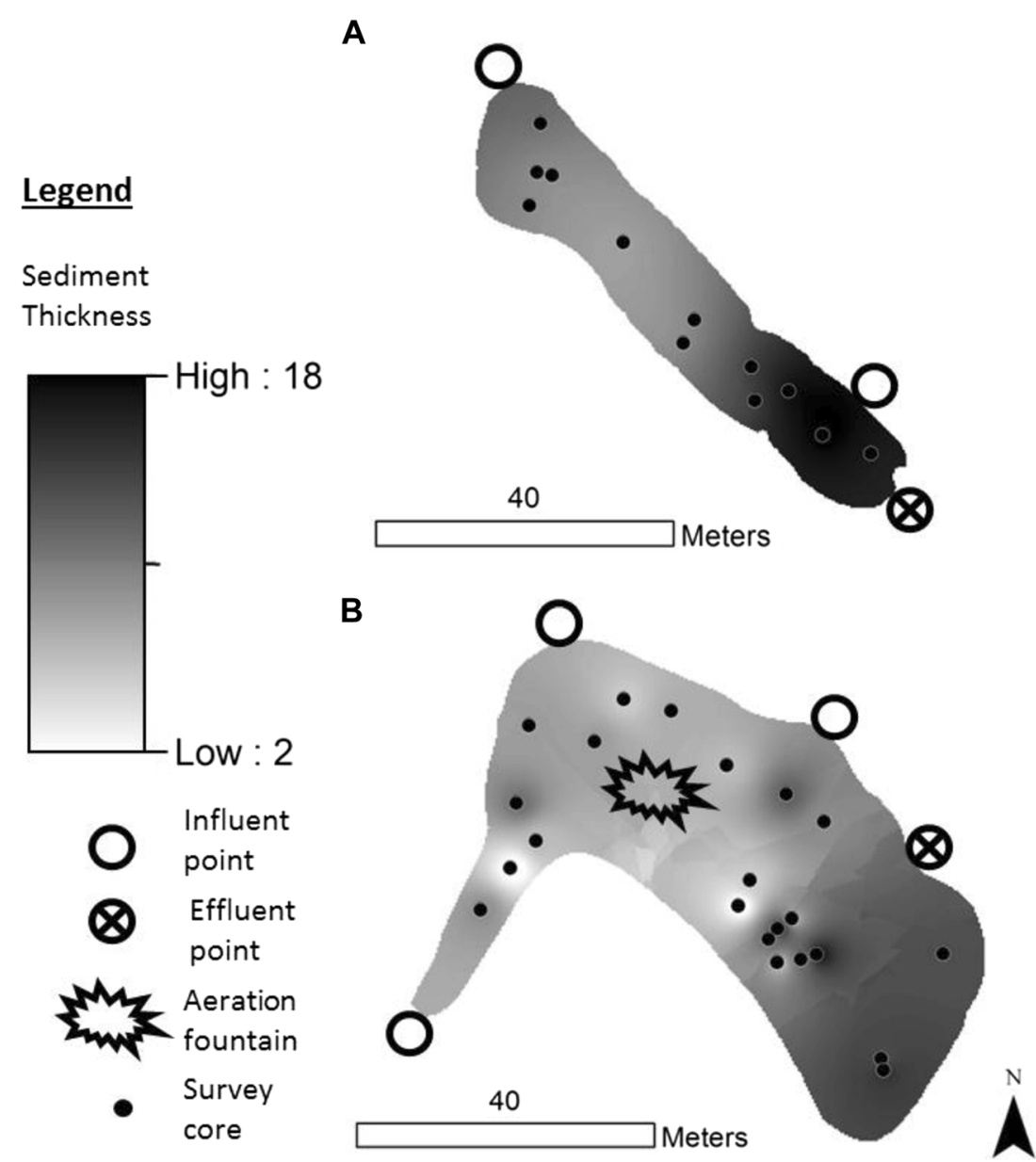

Figure 2. Maps of sediment thickness from two example ponds. Gray scale depicts sediment thickness, ranging from 2 to $18 \mathrm{~cm}$. A Pond 14 shows a gradient in sediment distribution with greatest accumulation by influent points. B Pond 13 pond shows a patchy distribution of sediments. Both ponds are from communities of similar development density and have similar landscaping

\section{$N$-alkane Biomarkers}

Reported alkane biomarker chain lengths ranged from $\mathrm{C}_{17}$ to $\mathrm{C}_{32}$ and generally showed a bimodal distribution with peaks at $\mathrm{C}_{17}$ and $\mathrm{C}_{29}$. The mean chain length was $26 \pm 1.9$, indicating a greater abundance of long chain $n$-alkanes. Carbon normalized $n$-alkane concentrations were variable (median $211 \mathrm{\mu g} \mathrm{g}^{-1} \mathrm{C}$, range $19.2 \pm 4.4-$ $645 \pm 306 \mu \mathrm{g} \mathrm{g}^{-1} \mathrm{C}$ ), yet significantly correlated with \%Ip $\left(R^{2}=0.57, p=0.002\right)$. This positive relationship was driven by the long chain length $n$ alkanes; the $\mathrm{C}$ normalized concentrations of $\mathrm{C}_{29}+\mathrm{C}_{31}$ ranged from $6.2 \pm 0.01$ to $247 \pm 117 \mu \mathrm{g} \mathrm{g}^{-1} \mathrm{C}$, with a median of $76.7 \mu \mathrm{g} \mathrm{g}^{-1}$ C (long chain $n$-alkanes versus \%Ip $R^{2}=0.52$, $p=0.004)$. In contrast, there was no significant relationship between $\mathrm{C}$ normalized short chain $n$ alkane concentrations and \% Ip $\quad\left(R^{2}=0.04\right.$, $p=0.45)$. The $\mathrm{C}$ normalized concentration of short chain $n$-alkanes $\left(\mathrm{C}_{17}+\mathrm{C}_{19}\right)$ was generally much lower, ranging from $4.1 \pm 2.3$ to $123 \pm 38 \mu \mathrm{g} \mathrm{g}^{-1}$ C, with a median of $18.2 \pm 29.5 \mu \mathrm{g} \mathrm{g}^{-1} \mathrm{C}$. One pond, Pond 11, was an outlier with a short length $n$-alkane concentration of $123 \pm 38 \mu \mathrm{g} \mathrm{g}^{-1} \mathrm{C}, 3$ times higher than the next closest pond, and 3.3 standard deviations above the mean. This was the only pond that contains a significant pond sediment algal biomass signal. The pond was also anomalous in that within its catchment, there were large patches (diameter 2-6 m) of lawn that lacked grass, exposing bare sandy soils, which showed visual evidence or erosion. It is possible that this poorly stabilized landscape resulted in high loading of mineral constituents to sediments. It was hypothesized that these mineral constituents were driving sediment accumulation and burying algal 
Table 2. Sediment Accumulation Characteristics and Biomarker Index Results, Ordered by \%Ip

\begin{tabular}{|c|c|c|c|c|c|c|}
\hline \multirow[t]{2}{*}{ Pond ID } & \multirow[t]{2}{*}{ Sediment volume $\left(\mathrm{m}^{3}\right)$} & \multirow[t]{2}{*}{$\%$ Filled } & \multirow[t]{2}{*}{$\operatorname{AR}\left(\mathrm{cm} \mathrm{y}^{-1}\right)$} & \multirow[t]{2}{*}{ Dry bulk density $\left(\mathrm{g} \mathrm{cm}^{-3}\right)$} & \multicolumn{2}{|c|}{ Biomarker indices } \\
\hline & & & & & TARHC & Paq \\
\hline 1 & $50 \pm 5.8$ & $1.5 \pm 0.2$ & $0.088 \pm 0.01$ & $0.39 \pm 0.06$ & $2.4 \pm 1.2$ & $0.23 \pm 0.07$ \\
\hline 2 & $47 \pm 7.7$ & $1.0 \pm 0.2$ & $0.062 \pm 0.01$ & $0.51 \pm 0.12$ & $1.0 \pm 0.1$ & $0.43 \pm 0.06$ \\
\hline 3 & $1613 \pm 91$ & - & $0.20 \pm 0.02$ & $0.30 \pm 0.11$ & $3.0 \pm 0.1$ & $0.30 \pm 0.08$ \\
\hline 4 & $201 \pm 14$ & - & $0.26 \pm 0.03$ & $0.32 \pm 0.07$ & $4.6 \pm 3.0$ & $0.33 \pm 0.01$ \\
\hline 5 & $168 \pm 23$ & - & $0.12 \pm 0.02$ & $0.29 \pm 0.09$ & $2.6 \pm 2.0$ & $0.49 \pm 0.02$ \\
\hline 6 & $67 \pm 2.1$ & $9.1 \pm 0.3$ & $0.30 \pm 0.02$ & $0.27 \pm 0.03$ & $9.4 \pm 2.7$ & $0.24 \pm 0.03$ \\
\hline 7 & $70 \pm 2.0$ & $15.2 \pm 0.4$ & $0.34 \pm 0.02$ & $0.40 \pm 0.04$ & $10.8 \pm 5.2$ & $0.19 \pm 0.02$ \\
\hline 8 & $333 \pm 27$ & $10.1 \pm 0.8$ & $0.33 \pm 0.03$ & $0.14 \pm 0.01$ & $7.9 \pm 1.9$ & $0.14 \pm 0.09$ \\
\hline 9 & $206 \pm 7.2$ & $5.0 \pm 0.2$ & $0.41 \pm 0.03$ & $0.34 \pm 0.14$ & $11.2 \pm 1.8$ & $0.17 \pm 0.01$ \\
\hline 10 & $283 \pm 8.1$ & $17.5 \pm 0.5$ & $0.48 \pm 0.02$ & $0.20 \pm 0.02$ & $6.1 \pm 0.8$ & $0.24 \pm 0.03$ \\
\hline 11 & $63 \pm 5.8$ & $3.1 \pm 0.3$ & $0.50 \pm 0.08$ & $0.29 \pm 0.02$ & $0.7 \pm 0.1$ & $0.43 \pm 0.06$ \\
\hline 12 & $113 \pm 3.7$ & $6.6 \pm 0.2$ & $0.47 \pm 0.03$ & $0.30 \pm 0.09$ & $12.6 \pm 2.4$ & $0.14 \pm 0.03$ \\
\hline 13 & $214 \pm 5.5$ & $5.5 \pm 0.1$ & $0.50 \pm 0.03$ & $0.38 \pm 0.07$ & $11.6 \pm 6.8$ & $0.22 \pm 0.07$ \\
\hline 14 & $111 \pm 1.9$ & $14.2 \pm 0.2$ & $0.50 \pm 0.03$ & $0.30 \pm 0.07$ & $11.3 \pm 0.9$ & $0.21 \pm 0.01$ \\
\hline Mean & 253 & 8.1 & 0.33 & 0.32 & 6.8 & 0.27 \\
\hline Median & 141 & 6.6 & 0.34 & 0.30 & 7.0 & 0.24 \\
\hline SD & 387 & 5.4 & 0.15 & 0.09 & 4.2 & 0.11 \\
\hline
\end{tabular}

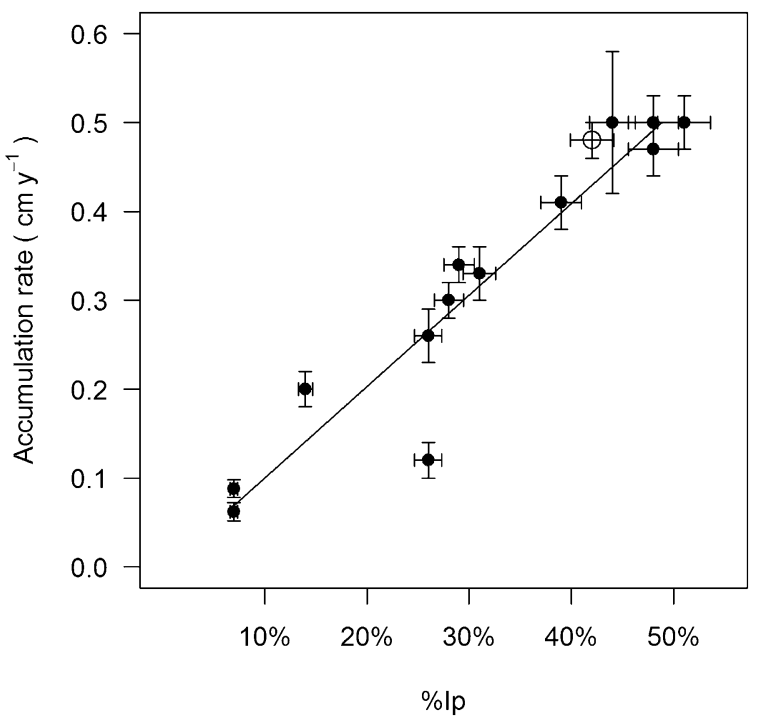

Figure 3. Simple linear regression between pond sediment accumulation rate and catchment \%Ip. The regression is significant $\left(R^{2}=0.90, p<0.001\right)$, with a regression equation of: $y=1.03 \times 10^{-2} x-0.003$. The exact age of the pond identified by an hollow circle is unknown as it appears to be a historic drainage that was converted to a stormwater pond in 1973. The 1973 date was used as the pond age

biomass before it could be mineralized at the sediment surface interface. As such, this pond was removed from index regression analyses.
$\mathrm{TAR}_{\mathrm{HC}}$ ranged from $0.73 \pm 0.01$ to $12.6 \pm 2.4$, with a mean of $6.8 \pm 4.2$, while $\mathrm{P}_{\mathrm{aq}}$ ranged from $0.14 \pm 0.09-0.49 \pm 0.02$ with a mean of $0.27 \pm 0.11$ (Table 2). The $\mathrm{TAR}_{\mathrm{HC}}$ values above 1 and $\mathrm{P}_{\mathrm{aq}}$ values below 0.5 indicate that long chain $n$ alkanes dominate in both indices. $\mathrm{TAR}_{\mathrm{HC}}$ had a significant positive correlation with \%Ip, perimeter/PA, and accumulation rate, and a negative correlation with SA/CA (Table 3, Figure 4). $\mathrm{TAR}_{\mathrm{HC}}$ had no correlation with TPP $\left(R^{2}=0.28, p=0.07\right)$. $\mathrm{P}_{\mathrm{aq}}$ had a negative correlation with perimeter: $\mathrm{SA}$, accumulation rate, and TPP $\left(R^{2}=0.35, p=0.034\right)$, while it was positively correlated with SA/CA (Table 3).

\section{Sediment Carbon and Nutrient Composition}

Mean sediment $\mathrm{C}, \mathrm{N}$, and $\mathrm{P}$ concentrations (\% dry mass) were determined for each pond (Table 4). Pond sediment $\mathrm{C}$ concentrations varied from 6.84 to $21.5 \%$ dry wt with a mean concentration across all ponds of $12.0 \pm 4.0 \%$ dry wt (Table 4 ). Individual pond $\mathrm{N}$ concentrations ranged from 0.40 to $1.26 \%$ dry wt, and mean of $0.63 \pm 0.23 \%$ dry wt across all ponds (Table 4). TPP concentrations varied from 0.080 to $0.344 \%$ dry wt with a mean of $0.190 \pm 0.087 \%$ dry wt across all ponds (Table 4). PIP values ranged from 0.037 to $0.244 \%$ dry wt with a mean of $0.130 \pm 0.061 \%$ dry wt. PIP represented $68 \pm 9 \%$ of the total P pool. POP varied 
Table 3. $R^{2}$ and $p$ Values (in parentheses) for Simple Linear Regressions Between Various Sediment and Morphometric Variables

\begin{tabular}{|c|c|c|c|c|c|c|}
\hline & $\%$ Ip & & Perim/SA & & SA/CA & \\
\hline $\operatorname{AR}\left(\mathrm{cm} \mathrm{y}^{-1}\right)$ & $0.90(+)$ & $(<0.001)$ & $0.44(+)$ & $(0.009)$ & $0.44(-)$ & $(0.009)$ \\
\hline Bulk density $\left(\mathrm{g} \mathrm{cm}^{-3}\right)$ & 0.20 & $(0.11)$ & 0.03 & $(0.56)$ & 0.03 & $(0.56)$ \\
\hline TAR & $0.73(+)$ & $(<0.001)$ & $0.65(+)$ & $(0.002)$ & $0.65(-)$ & $(<0.001)$ \\
\hline Paq & 0.30 & $(0.054)$ & $0.33(-)$ & $(0.040)$ & $0.45(+)$ & $(0.012)$ \\
\hline $\mathrm{C}$ burial $\left(\mathrm{g} \mathrm{m}^{-2} \mathrm{y}^{-1}\right)$ & $0.78(+)$ & $(<0.001)$ & $0.58(+)$ & $(0.002)$ & 0.19 & $(0.12)$ \\
\hline $\mathrm{N}$ burial $\left(\mathrm{g} \mathrm{m}^{-2} \mathrm{y}^{-1}\right)$ & $0.75(+)$ & $(<0.001)$ & $0.60(+)$ & $(0.001)$ & 0.25 & $(0.07)$ \\
\hline P burial $\left(\mathrm{g} \mathrm{m}^{-2} \mathrm{y}^{-1}\right)$ & $0.56(+)$ & $(0.002)$ & $0.29(+)$ & $(0.047)$ & 0.12 & $(0.22)$ \\
\hline $\mathrm{C} / \mathrm{P}$ (molar) & 0.16 & $(0.16)$ & 0.08 & $(0.31)$ & 0.27 & $(0.06)$ \\
\hline $\mathrm{C} / \mathrm{N}$ (molar) & $0.36(+)$ & $(0.023)$ & 0.05 & $(0.46)$ & 0.01 & $(0.87)$ \\
\hline $\mathrm{N} / \mathrm{P}$ (molar) & $0.33(-)$ & $(0.030)$ & 0.13 & $(0.21)$ & 0.27 & $(0.06)$ \\
\hline C (\% dry wt) & 0.14 & $(0.18)$ & 0.04 & $(0.50)$ & 0.05 & $(0.47)$ \\
\hline $\mathrm{N}(\%$ dry wt) & 0.02 & $(0.68)$ & 0.02 & $(0.61)$ & 0.11 & $(0.25)$ \\
\hline TPP (\% dry wt) & 0.26 & $(0.060)$ & 0.06 & $(0.39)$ & 0.01 & $(0.77)$ \\
\hline POP (\% dry wt) & 0.08 & $(0.34)$ & 0.01 & $(0.70)$ & 0.02 & $(0.68)$ \\
\hline
\end{tabular}

Bolded are values are significant $(p<0.05)$ and negative $(-)$ and positive $(+)$ symbols denote whether relationship is positive or negative. Perim/SA is the perimeter-to-surface area ratio, SA/CA is the ratio of a pond's surface area to its catchment.

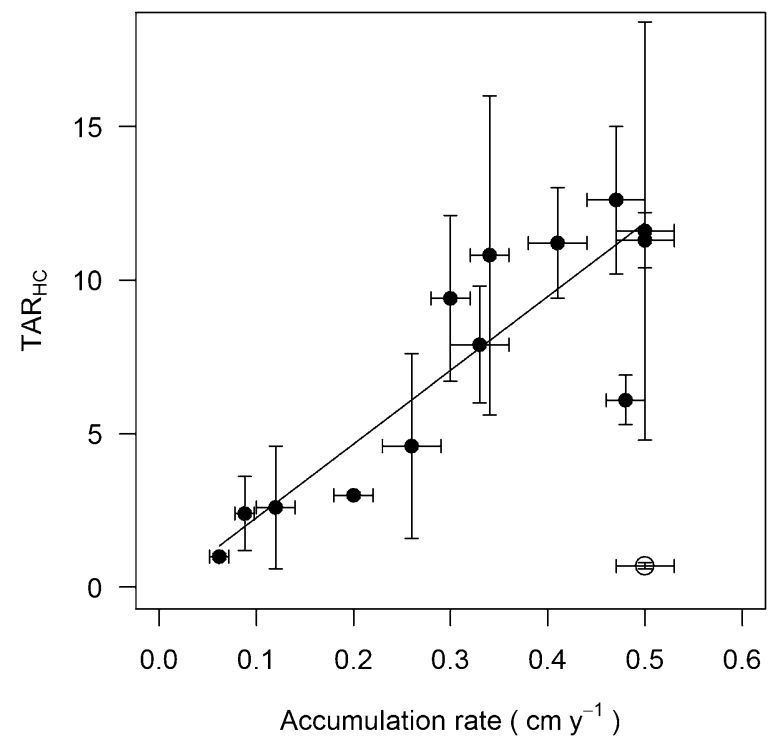

Figure 4. Linear regression between sediment accumulation rate and $\mathrm{TAR}_{\mathrm{HC}}$. Correlation is significant $\left(R^{2}=0.77, p<0.001\right), y=24 x-0.13$. The open diamond represents Pond 11 (hollow circle) and was removed from the regression. If Pond 11 is included, the regression remains significant $(p=0.012)$

from 0.026 to $0.139 \%$ dry wt with a mean of $0.058 \pm 0.029 \%$ dry wt (Table 4 ). The variability of $\mathrm{C}$ and nutrient concentrations across ponds was independent of $\%$ Ip, perimeter/SA ratio, or SA/CA ratio (Table 3). $\mathrm{C}$ and $\mathrm{N}$ concentrations were neg- atively correlated with sediment bulk density (C: $\left.R^{2}=0.46, p=0.008 ; \mathrm{N}: R^{2}=0.39, p=0.016\right)$. TPP, PIP, and POP showed no correlation with bulk density. Given the correlations between sediment bulk density, sediment $\mathrm{C}$ and $\mathrm{N}$; these densities exhibited slightly less variability across ponds. Mean C was $24.3 \pm 6.16 \mathrm{~g} \mathrm{~cm}^{-3}$ (range 14.1 $\left.32.4 \mathrm{~g} \mathrm{~cm}^{-3}\right), \quad \mathrm{N}$ was $1.2 \pm 0.24 \mathrm{~g} \mathrm{~cm}^{-3}(0.75-$ $\left.1.6 \mathrm{~g} \mathrm{~cm}^{-3}\right)$, and TPP was $0.489 \pm 0.198 \mathrm{~g} \mathrm{~cm}^{-3}$ $\left(0.200-0.896 \mathrm{~g} \mathrm{~cm}^{-3}\right)$ (Table 4). The variability of $\mathrm{C}$ and nutrient densities were also independent of $\%$ Ip, perimeter: SA and SA/CA.

Sediment depth profiles revealed variable patterns of down core nutrient distribution. Significant negative correlations were found for $\mathrm{C}$ and $\mathrm{N}$ versus depth in 27 of 29 cores $(p<0.05)$. Single sample $t$ tests rejected the null hypothesis that regression slopes were equal to zero (C, $p<0.001) ; \mathrm{N}, p<0.001)$. Depth profiles further showed $\mathrm{N}$ declines more rapidly than $\mathrm{C}$, which was further confirmed by a matched pairs $t$ test of the two slopes $(p<0.001)$. TPP, PIP, and POP versus depth profiles showed greater variability relative to that of $\mathrm{C}$ and $\mathrm{N}$. Of the 28 cores sampled for TPP, 10 had significant negative correlations ( $p$ values $<0.05), 3$ had significant positive correlations $(p<0.05)$, and the remaining 15 had no significant correlation $(p>0.05)$. A single sample $t$ test failed to reject the null hypothesis that slopes of TPP versus depth were equal to zero $(p=0.064)$. For PIP, 6 cores had significant negative correla- 


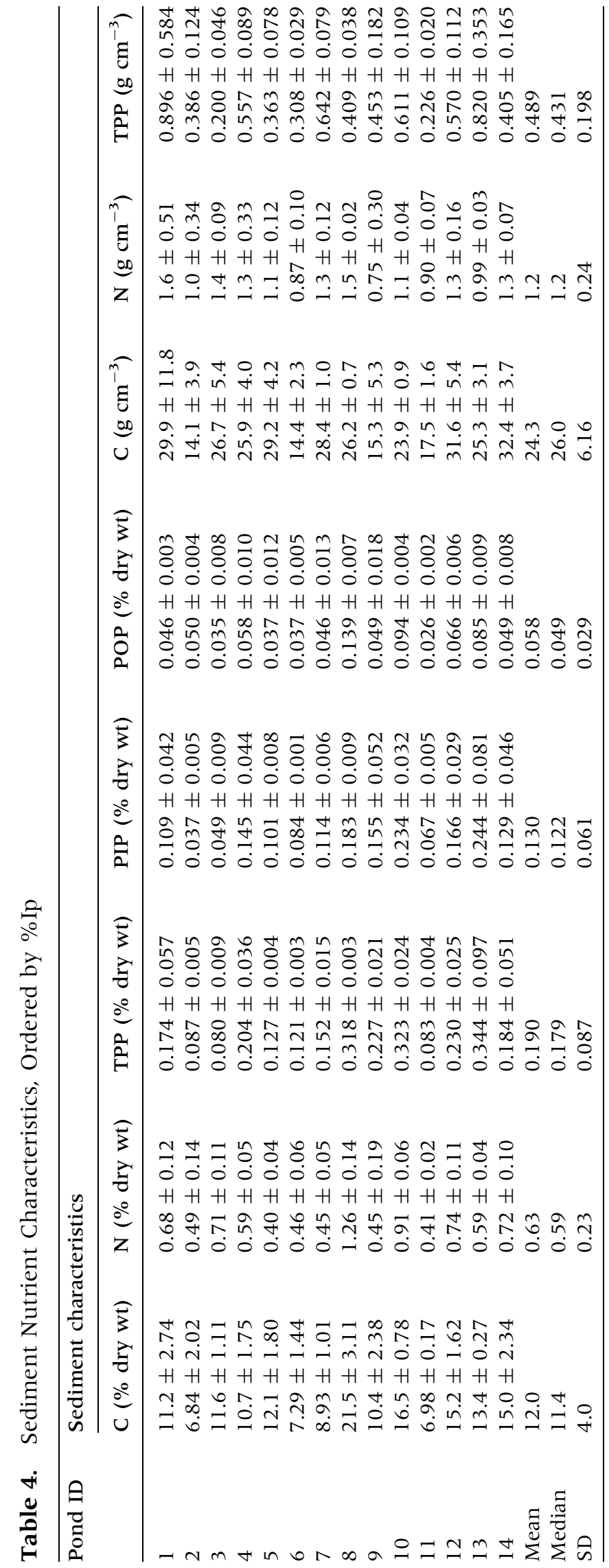


tions with depth $(p<0.05), 7$ had significant positive correlations $(p<0.05)$, and the remaining 15 had no significant correlation $(p>0.05)$. A single sample $t$ test failed to reject the null hypothesis that slopes of PIP versus depth were equal to zero $(p=0.66)$. POP values generally had greater errors than TPP, PIP, C, or N as POP was calculated as the difference between TPP and PIP (difference between two large numbers). For POP, 10 had significant negative correlations with depth $(p<0.05), 4$ had significant positive correlations $(p<0.05)$, and the remaining 14 had no significant correlation $(p>0.05)$. A single sample $t$ test failed to reject the null hypothesis that slopes of POP versus depth were equal to zero $(p=0.81)$.

Sediment stoichiometric ratios showed a twofold to fourfold variability among ponds (Table 5). The mean of molar C/P ratio was 184 (range 91.9-377), $\mathrm{C} / \mathrm{N}$ ratio was 24.3 (16.4-32.6), N/TPP ratio was 8.7 (4.3-19.0), and N/POP ratio was 26.0 (13.1-44.8). The mean ratio of $\mathrm{C} / \mathrm{N}$ at the sediment surface $(0-$ $1 \mathrm{~cm}$ section) was $18.2(15.5-24.8)$. The $\mathrm{C} / \mathrm{N}$ ratio calculated from the slope of the regression between $\mathrm{C}$ and $\mathrm{N}$ of all sections was $15.3\left(R^{2}=0.84\right.$, $n=417, p<0.001)$. The ratio of C/TPP showed no correlation with any of the morphometric variables, while $\mathrm{C} / \mathrm{N}$ was directly correlated with catchment \%Ip, and N/TPP was inversely correlated with \%Ip (Table 3). These correlations were largely driven by changes in $\mathrm{C}$ and $\mathrm{P}$ concentrations.

\section{Carbon and Nutrient Burial Rates}

Burial rates of $\mathrm{C}, \mathrm{N}$, and $\mathrm{P}$ spanned more than an order of magnitude across all ponds (Table 5). Mean C burial was $80 \pm 44 \mathrm{~g} \mathrm{~m}^{-2} \mathrm{y}^{-1}$ (range 8.7$\left.161 \mathrm{~g} \mathrm{~m}^{-2} \mathrm{y}^{-1}\right)$. Mean nitrogen burial was $3.7 \pm 1.8 \mathrm{~g} \mathrm{~m}^{-2} \mathrm{y}^{-1}$ (range 0.65-6.43 $\mathrm{g} \mathrm{m}^{-2} \mathrm{y}^{-1}$ ). Mean TPP burial was $1.61 \pm 1.07 \mathrm{~g} \mathrm{~m}^{-2} \mathrm{y}^{-1}$ (range $0.238-4.13 \mathrm{~g} \mathrm{~m}^{-2} \mathrm{y}^{-1}$ ). All $\mathrm{C}$ and nutrient burial rates were directly correlated with catchment \%Ip (Table 3). The equations for the regression lines between each burial rate and \%Ip were: C $y=2.75 x-6.5 ; \quad \mathrm{N} \quad y=0.11 x+0.34 ; \quad$ TPP $y=5.7 \times 10^{-2} x-0.17 . \mathrm{C}, \mathrm{N}$, and P were also directly correlated with perimeter: SA (Table 3 ).

\section{Discussion}

\section{Stormwater Ponds Have Similar Biogeochemistry to Natural Lakes}

Historically, the study of limnology has been skewed toward larger lentic systems; only recently has the ecological significance of smaller water bodies been recognized (Downing 2010; Cheng and Basu 2017). Although the importance of small water bodies is gaining more attention, there is still a knowledge gap surrounding the response of small lentic systems to urban and suburban development. The impact of urbanization on the ecology, hydrology, and biogeochemistry of lotic systems has been well documented and even given a name, the "urban stream syndrome" (Walsh and others 2005, 2012; Booth and others 2016). An equally comprehensive body of research or "diagnosis" has not been similarly reached for urban lentic systems. This may in part be explained by the fact that many, if not most of these urban lentic systems, were specifically created in response to hydrologic modification associated with urban development; stormwater management. Nonetheless, it is clear that these created systems maintain an internal biogeochemistry that can greatly influence the functional role they play in the larger urban/suburban ecosystem (Williams and others 2013). The goal of this project was to quantify the role stormwater ponds play in the biogeochemical cycling of $\mathrm{C}, \mathrm{N}$, and $\mathrm{P}$ by quantifying rates of burial in sediments. With respect to these processes, stormwater ponds show a striking similarity of function to larger, "natural" lakes. For the purposes of this discussion, the "natural" refers to large non-artificial lakes (that is, lakes formed by natural geologic processes rather than having been created for a specific human purpose). This distinction is independent of anthropogenic impacts to the lake and its catchment, as such "natural" does not imply "pristine".

Biogeochemical similarities between ponds and natural lakes are apparent in sediment $\mathrm{C}$ and nutrient concentration. The mean pond sediment $\mathrm{C}$ concentration was $12 \%$ dry mass, comparable to values reported for natural lakes (Table 6) (Brunskill and others 1971; Gorham and others 1974; Dean and others 1993). Of particular interest is the similarity of stormwater pond sediments to sediments of 46 Minnesota lakes with catchments classified as undisturbed forest or prairie; the mean C concentration was also $12 \%$ by dry mass (Dean and others 1993). In contrast to their similarity with natural lakes, stormwater pond sediments show threefold to fourfold greater \% content relative to reservoir sediments from agricultural and mixed land use catchments (Brunskill and others 1971; Gorham and others 1974; Dean and others 1993; Downing and others 2008; Knoll and others 2014). The differences in sediments \% C content in pond/lakes and reservoirs are likely ex- 


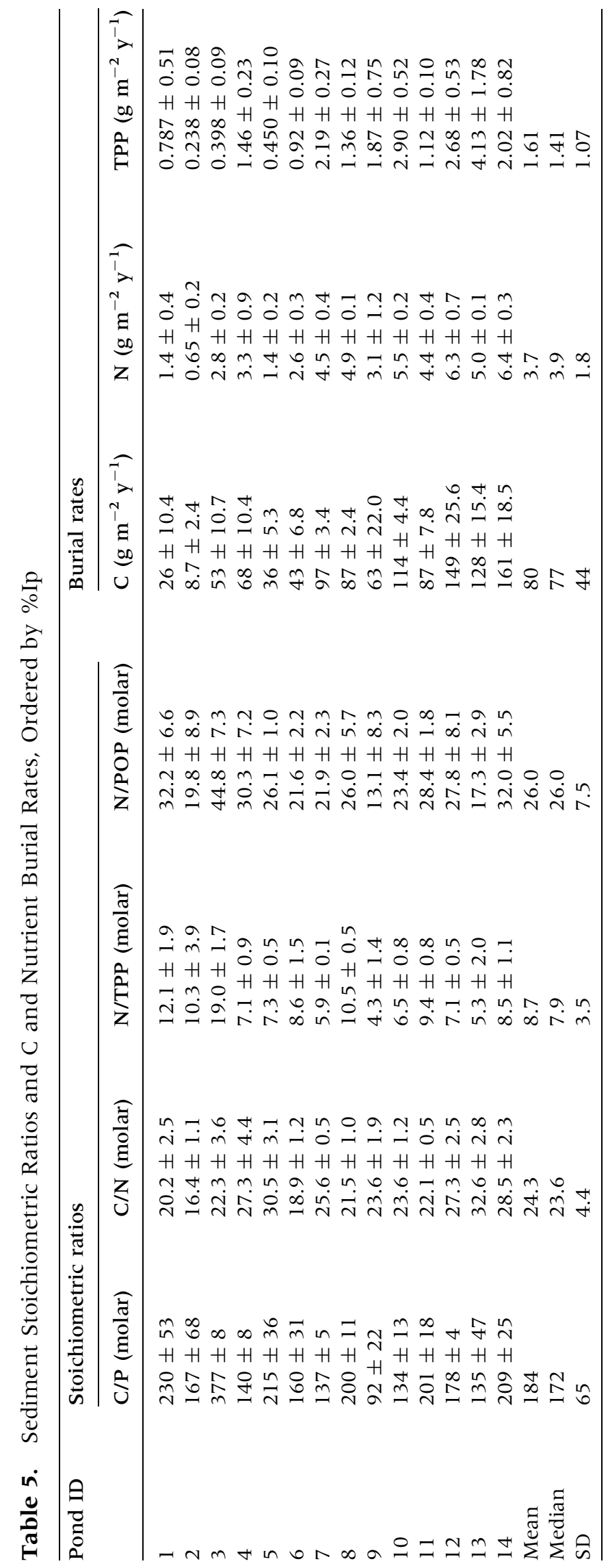




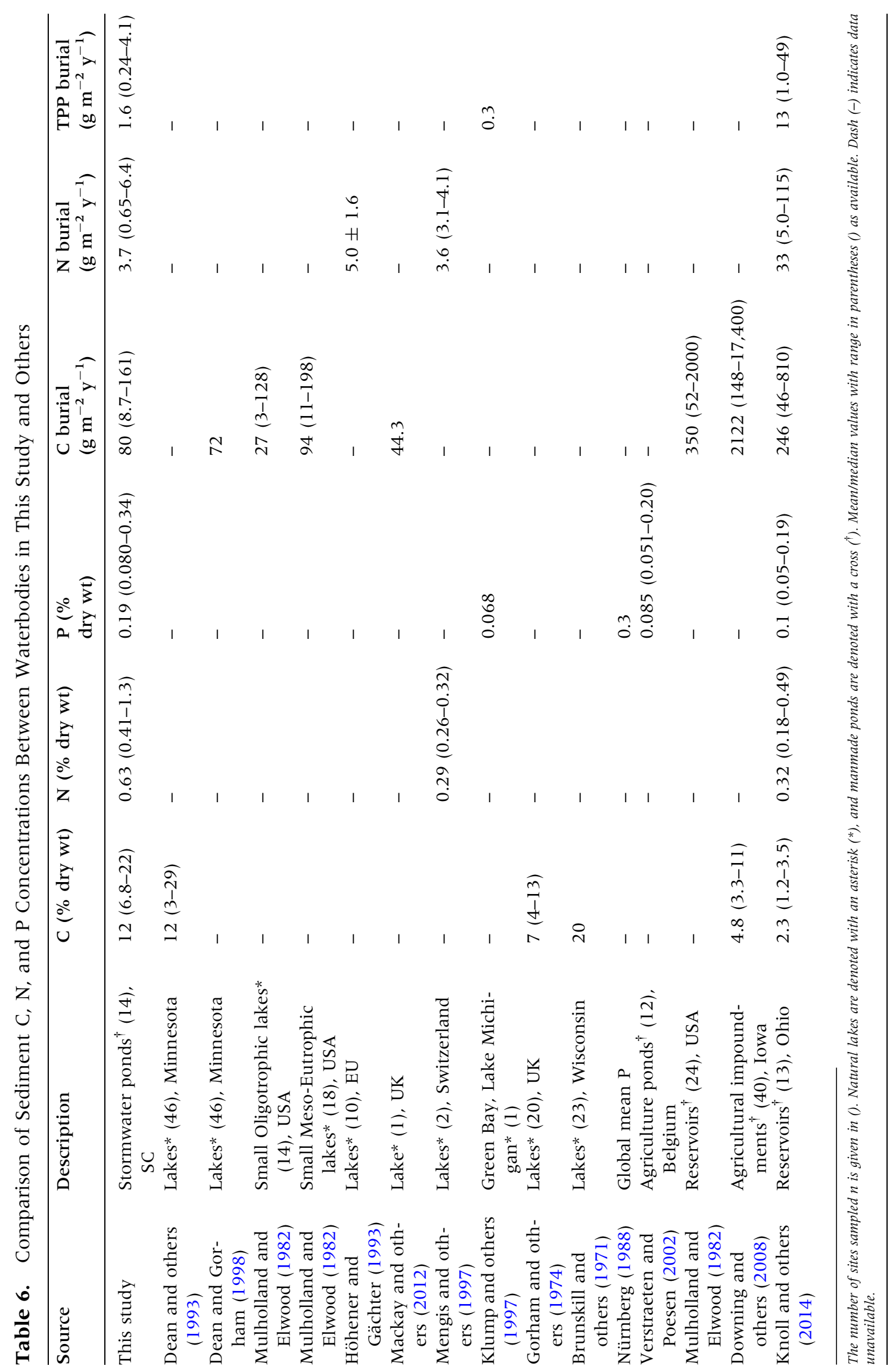


plained by patterns of water flow management and mineral sediment loading. Reservoirs and impoundments are dammed waterbodies with continuous stream inputs, which may provide a means for greater transport of suspended solids to basins. This increased load of mineral sediments results in much higher total $\mathrm{C}$ burial rates, but much more dilute organic $\mathrm{C}$ content on a per mass or volume basis. In contrast, the residential stormwater ponds sampled in this study only receive inputs during rain events. Furthermore, the communities within these ponds' catchments have well maintained landscaping and lawn care, reducing the potential for erosion and transport of mineral sediments. The notable exception is the Pond 11 community, where bare patches of lawn were common, revealing sandy soils. Sediments from this pond have a mean $\mathrm{C}$ concentration of $7.0 \%$ dry mass (Table 2 ), well below the mean of all the stormwater ponds. This argues for greater mineral loading relative to biomass loading in Pond 11.

In contrast to studies of $\mathrm{C}$ content, published data for $\mathrm{N}$ and $\mathrm{P}$ concentrations in lake, impoundment or pond sediments are more limited and much more variable. With respect to $\mathrm{N}$, mean stormwater pond sediments were approximately double the values reported for both natural lakes and reservoirs (Table 6) (Höhener and Gächter 1993; Klump and others 1997; Mengis and others 1997; Mackay and others 2012; Knoll and others 2014). The relatively high $\mathrm{N}$ concentrations reported in stormwater ponds may indicate low rates of denitrification in young sediments. Stormwater sediment $\mathrm{P}$ concentrations fell between the reported global mean value and values of other artificial systems (Nürnberg 1988; Verstraeten and Poesen 2002; Gälman and others 2008; Knoll and others 2014).

This study found that rates of $\mathrm{C}, \mathrm{N}$, and $\mathrm{P}$ burial were directly correlated with \%Ip (versus individual concentrations) which demonstrates that the bulk sedimentation drives nutrient burial rates (Table 3). Though \%Ip is correlated with a myriad of anthropogenic impacts, it directly influences the region's hydrology by greatly increasing the quantity and velocity of runoff water, which subsequently increases the load of suspended particulate matter (Corbett and others 1997a; Walsh and others 2005; Grimm and others 2008; Jacobson 2011; Nagy and others 2011; Fletcher and others 2013). This high load of suspended particulate matter, allowed to settle in the stormwater pond's basin, can ultimately lead to increased bulk mass accumulation and subsequent burial of particleassociated $\mathrm{C}$ and nutrients.

To compare ponds to natural lakes, comparisons must be made on similar scales. Thus, catchment to catchment comparisons of ponds and natural lakes is not possible. Broadly speaking, however, pond mean burial rates were comparable to lakes from catchments of varying land use (Table 6). The mean $\mathrm{C}$ burial rate identified in this study $\left(80 \mathrm{~g} \mathrm{~m}^{-2} \mathrm{y}^{-1}\right.$, Table 4) was well within the range of mean burial rates reported in the literature for natural lakes, though there was variability within these data (Table 6). The impacted nature of stormwater ponds appeared to sequester $\mathrm{C}$ at rates more comparable to potentially impacted meso-eutrophic lakes $\left(94 \mathrm{~g} \mathrm{~m}^{-2} \mathrm{y}^{-1}\right)$ as opposed to a group of less likely impacted oligotrophic lakes $\left(27 \mathrm{~g} \mathrm{~m}^{-2} \mathrm{y}^{-1}\right.$ ) (Mulholland and Elwood 1982). However, a group of 46 lakes from un-impacted forest and prairie catchments showed mean $\mathrm{C}$ burial of $72 \mathrm{~g} \mathrm{~m}^{-2} \mathrm{y}^{-1}$, a rate very similar to that of stormwater ponds (Dean and Gorham 1998). Comparison with reservoirs showed more stark contrasts, as $\mathrm{C}$ burial rates of stormwater ponds and natural lakes, were one to two orders of magnitude below the burial rates of reservoirs and impoundments (Table 6) (Mulholland and Elwood 1982; Höhener and Gächter 1993; Dean and Gorham 1998; Downing and others 2008; Mackay and others 2012; Knoll and others 2014).

Direct measurements of $\mathrm{N}$ and $\mathrm{P}$ burial rates are infrequently reported in the literature. However, this study's mean $\mathrm{N}$ burial $\left(3.8 \mathrm{~g} \mathrm{~m}^{-2} \mathrm{y}^{-1}\right)$ was comparable to those of European lakes, while remaining an order of magnitude lower than reservoir N burial rates (Mengis and others 1997; Knoll and others 2014). Pond $P$ burial rates $\left(1.6 \mathrm{~g} \mathrm{~m}^{-2} \mathrm{y}^{-1}\right.$ ) were also an order of magnitude below the mean burial rate of 13 reservoirs (Table 6) (Knoll and others 2014). Only a single methodologically comparable $\mathrm{P}$ burial rate was found in the literature for a natural lake, Green Bay, with a reported $P$ burial rate below that of stormwater ponds (Table 6) (Klump and others 1997). The authors hypothesized that the consistently higher $\mathrm{C}, \mathrm{N}$, and $\mathrm{P}$ burial rates of reservoirs were a result of their hydrology. At the local pond to pond scale, it is hypothesized that impervious surfaces increase runoff inputs to the pond, leading to higher burial rates. At the larger scale, reservoirs receive constant and high hydraulic inputs from their local river or stream. The constant inputs of suspended solids and nutrients to reservoirs thus lead to high rates of bulk sediment burial, even though they maintain lower nutrient concentrations. 
With respect to the sequestration of $\mathrm{C}, \mathrm{N}$, and $\mathrm{P}$, the stormwater ponds appear to function quite similarly to natural lakes. These similarities do not imply that pond ecosystems are un-impacted by urban development; by their very design, stormwater detention ponds are intended to receive and retain the loads of nutrient, microbial, heavy metals, and organic pollutants from their developed catchments, which can all degrade environmental quality of pond waters and sediments. Rather, the results of this study suggest that hydrologic flow is the dominant factor in $\mathrm{C}$ and nutrient burial, which shows the importance of bulk sediment accumulation to lentic sequestration of $\mathrm{C}$ and nutrients.

\section{Sediment Accumulation Rates Were Low, Predicted by Impervious Surface Coverage}

In addition to the role sediment accumulation plays in $\mathrm{C}$ and nutrient burial, stormwater pond sediment accumulation is a significant factor in pond management. Although the State of South Carolina requires dredging of stormwater detention ponds when they have lost $25 \%$ of their original design volume (SCDHEC 2005), sedimentation rates observed in this study indicate their anticipated dredging interval of 5-10 years greatly overestimates the frequency of dredging required to maintain pond function. Regardless of pond morphology and development intensity, coastal stormwater ponds have much lower sedimentation rates than previously anticipated (Table 2). This study's estimates predict it will take a median of 68 years (range 36.3-515 years) for the stormwater ponds to reach the $25 \%$ volume displacement limit imposed by the State (SCDHEC 2005). The major predictor of pond sedimentation rate was not pond morphology, but rather the relative percentage of impervious surfaces, such as roads, parking lots, and buildings surrounding the pond (Figure 3, Table 3).

The strong relationship between sedimentation rate and impervious surfaces (\%Ip, $R^{2}=0.90$, Figure 3 ) is likely driven by the impacts of impervious surfaces on local hydrology. Stormwater ponds, as settling basins, are very efficient particle traps (Verstraeten and Poesen 2000), so it is likely that pond sediment accumulation rates are controlled by suspended particulate input flux. As mentioned previously, impervious surfaces are known to increase the volume of runoff waters and the load of suspended particulate matter (Corbett and others 1997a; Grimm and others 2008; O'Driscoll and others 2010; Jacobson 2011; Nagy and others 2011; Walsh and others 2012; Fletcher and others 2013). The final result being ponds with greatest impervious surfaces have the greatest runoff fluxes bearing the greatest particulate loads, which lead to the greatest sediment accumulation rates.

The hypothesis that influent flux controls accumulation and burial rates would also explain trends seen in the literature when offline stormwater detention ponds are compared to online ponds and impoundments. The sediment accumulation rates reported in this study were comparable to 5 Pennsylvania stormwater ponds (no inflow, median 0.77, range $0.54-2.07 \mathrm{~cm} \mathrm{y}^{-1}$, Brainard and Fairchild 2012), but were significantly lower than those reported in agricultural impoundments (mean $5.9 \mathrm{~cm} \mathrm{y}^{-1}$, Downing and others 2008) and stream fed stormwater ponds (inflow, median 1.52, range $1.28-3.03 \mathrm{~cm} \mathrm{y}^{-1}$, Brainard and Fairchild 2012). These comparisons reveal the same pattern observed in $\mathrm{C}$ and nutrient burial, again suggesting that bulk accumulation drives $\mathrm{C}, \mathrm{N}$, and $\mathrm{P}$ sequestration.

\section{Terrestrial Biomass Drives Sediment Accumulation}

Given previous studies in lakes and reservoirs (Downing and others 2008; Anderson and others 2014), as well as previous observations that stormwater ponds of the Southeast generally promote high concentrations of algal biomass (Lewitus and others 2008), it was hypothesized that internal algal production would be the major source of organic matter to sediments. However, multiple indices showed that terrestrial biomass was the dominant source of sediment organic matter to SC coastal stormwater ponds. Sediment surface $\mathrm{C} / \mathrm{N}$ ratios were consistently greater than 10 (averaging $18.2 \pm 2.8$ ), indicating that pond sediments stored more terrestrial than algal biomass (Meyers and Ishiwatari 1993). Additionally, both biomarker indices (Table 2) showed that terrestrial signatures were significantly stronger than algal or aquatic macrophyte signals (Ficken and others 2000). For simplicity, the rest of the discussion focuses on the $\mathrm{TAR}_{\mathrm{HC}}$ index, as both $\mathrm{TAR}_{\mathrm{HC}}$ and $\mathrm{P}_{\mathrm{aq}}$ show similar patterns. The median $\mathrm{TAR}_{\mathrm{HC}}$ value of this study, 7.0, shows a significantly greater terrestrial signature than values reported in the North American Great Lakes (median 1.5) (Bourbonniere and Meyers 1996; Silliman and others 1996; Meyers 1997; Lu and Meyers 2009) though a significantly lower terrestrial signature than found in Russian rivers (range 17-80) (van Dongen and others 
2008). Although $\mathrm{TAR}_{\mathrm{HC}}$ does not provide absolute ratios of biomass, this index has been very useful for comparing relative changes through time or across features in an ecosystem (Bourbonniere and Meyers 1996; van Dongen and others 2008). In this study, the direct correlation between $\mathrm{TAR}_{\mathrm{HC}}$ and accumulation rate indicates that the greatest terrestrial signatures were observed in ponds with the greatest rates of sediment accumulation, again suggesting that terrestrial biomass drives sediment accumulation (Figure 3). We hypothesize that the dominance of terrestrial biomass in stormwater pond sediments is the result of high loading of terrestrial biomass and low rates of algal biomass burial.

With regard to the sources of terrestrial matter, just as the amount of impervious surface drove sedimentation rates (Figure 2), the proportion of terrestrial material was also strongly positively correlated with the amount of impervious surfaces. We hypothesize that though undeveloped catchments had greater terrestrial biomass, they lacked the runoff velocities required to transport biomass to the pond (Corbett and others 1997a). The higher runoff velocities from more developed catchments were more capable of transporting organic matter into ponds either as sheet flow over lawns or as channeled through storm drains (Jacobson 2011). Here, it is important to note that impervious surface coverage never exceeded about $50 \%$. Thus, at least half of each pond's catchment was open space, often taking the form of routinely fertilized and mowed grass lawns. These lawns produced large quantities of easily transported grass clippings, providing a great source of external, terrestrial, biomass to detention ponds. Ultimately the impacts of human development could increase the export of terrestrial biomass to receiving waters. It is also possible that the morphology of stormwater ponds increases their relative terrestrial load. Their small size inherently provides large perimeter-to-surface area ratios (Song and others 2013). As lawns generally run to the edge of the pond, there is great potential for terrestrial biomass inputs. Larger lakes have inherently lower perimeter-to-surface area ratios reducing the potential load of terrestrial biomass per unit surface area, but high terrestrial loading alone does not account for the observed low algal signature.

Algal blooms were observed in our stormwater ponds at the time of sampling and have also been documented previously in South Carolina stormwater ponds (Siegel and others 2011; Reed and others 2015). Our results indicate that, despite this internal production of algae, algal biomass was not ultimately stored in pond sediment. Therefore, the algal biomass must have had an alternative fate, which could be either direct export from the pond, as all ponds have a defined outlet structure, or remineralization within the pond water column. Pond volumes are designed such that they are well flushed during rain events, potentially removing suspended algal biomass (SCDHEC 2005). Additionally, algal biomass is thought to be more labile than terrestrial biomass and undergoes preferential microbial remineralization (Zehnder and Svensson 1986; Bastviken and others 2004). This study did show clear signs of organic matter mineralization processes occurring in buried sediments. There was a universal decline of $\mathrm{C}$ and $\mathrm{N}$ concentrations with depth, which is expected as over time; biomass is mineralized to labile products $\left(\mathrm{CO}_{2}, \mathrm{CH}_{4}, \mathrm{~N}_{2}, \mathrm{NO}_{3}{ }^{-}\right.$, $\mathrm{NH}_{4}{ }^{+}$). The oldest sediments have had the most time for mineralization processes to occur. $\mathrm{N}$ concentrations decreased more rapidly with depth than did C, which suggests preferential remineralization of $\mathrm{N}$ rich compounds (Benner 1991; Hopkinson and others 1997). P sediment depth profiles were more variable, showing no broad down core trends. This result is consistent with the more complex mechanisms responsible for binding $\mathrm{P}$ to sediments. There are various substances capable of binding inorganic $\mathrm{P}$, notably hydroxides of $\mathrm{Fe}(\mathrm{III}), \mathrm{Al}$, and $\mathrm{Ca}$ but also clay particles and humic material (Søndergaard and others 2003; Kopáček and others 2005). The relative abundances of these substances can impact the ability of sediments to retain P. For example, Fe(III) hydroxide-associated $\mathrm{P}$ sequestration is sensitive to redox and $\mathrm{pH}$ shifts, but if excess $\mathrm{Al}$ hydroxides are also present, $\mathrm{P}$ will not be released back into the dissolved phase in the event of reductive dissolution of $\mathrm{Fe}$ (III) complexes (Jacoby and others 1982; Søndergaard and others 2003; Kopáček and others 2005). Specific sediment P binding characteristics may further differ between ponds or even spatially within a single pond due to unique $\mathrm{pH}$ conditions or redox shifts, such as those associated with diurnal thermal stratification (Song and others 2013). Combined, these processes ultimately result in variable patterns of $\mathrm{P}$ sequestration. Nonetheless, the lack of stable gaseous phases and the particle reactive nature of $\mathrm{P}$ makes stormwater ponds efficient traps of $\mathrm{P}$, while soluble $\mathrm{N}$ is less readily retained (Comings and others 2000; Moore and Hunt 2012; Tafuri and Field 2012; Gold and others 2017).

A number of factors control microbial remineralization of $\mathrm{C}$ and therefore the missing algal biomass. Rates of microbial remineralization of organic $\mathrm{C}$ are controlled by temperature and oxygen 
availability (Zehnder and Svensson 1986; Bastviken and others 2004; Gudasz and others 2010). Large lakes and reservoirs commonly experience summer thermal stratification allowing hypolimnetic waters to remain between 4 and $10^{\circ} \mathrm{C}$ year round and become seasonally anoxic (Boehrer and Schultze 2008). The small size and shallow nature ( $1-3 \mathrm{~m}$ ) of South Carolina stormwater ponds alter their patterns of stratification. Small ponds may experience thermal stratification during the summer months though the duration of stratification varies widely from about 2 to 30 days per month (Song and others 2013). The thermal gradient of stratified stormwater ponds is generally less than that of lakes, exposing the benthos to higher temperatures (Song and others 2013). These findings are consistent with studies that show that some South Carolina ponds have sustained mean summer temperatures as high as $30^{\circ} \mathrm{C}$ and maintain near year round oxygen supply (Corbett and others 1997b; Serrano and DeLorenzo 2008). It is quite possible that higher temperatures and potentially greater oxygen availability allow stormwater ponds to experience greater rates of microbial mineralization than larger lakes (Downing 2010).

Also of note, it was determined from discussions with pond owners that several of the ponds in this study were regularly treated with algaecide to maintain aesthetic value while other ponds rarely, if ever, received algaecide treatment. Algaecide use was not quantified, which introduces an uncontrolled variable, potentially generating a source of error. Though pond waters were observed to have high algal biomass, and in at least some of the ponds the algae were routinely killed, the algal sediment signatures remained low and stable across ponds, and sediment accumulation predictions seem to be unaffected by the presence or absence of routine algaecide treatment. These findings further suggest the algal biomass is mineralized or exported before it can be buried.

\section{Stormwater Ponds as Regional C and Nutrient Sinks in the Urban Hydrology}

In urban systems, many of the drivers of biogeochemical cycles are controlled by humans, for example, impervious surface coverage and excess loading of nutrients from waste, fertilizer, and detergents (Kaye and others 2006). These anthropogenic impacts can alter local hydrology, degrading stream quality, and increase nutrient export to receiving waters (Walsh and others 2005; Booth and others 2016). Stormwater ponds are ultimately designed as engineering control measures to mitigate impacts of urbanization to local hydrology and water quality. As ponds are designed to intentionally intercept sediment and nutrient export via stormwater flows, ponds are hotspots of biogeochemical activity, where nutrients can be passed between oxidation states, organic, and inorganic forms. Previous studies have found that stormwater detention ponds provide variable, yet significant, removal of nutrients and pollutants (Wu and others 1996; Comings and others 2000; Mallin and others 2002). These previous studies have focused on the mass balance of influent and effluent. Our study addressed the removal of $\mathrm{C}$ and nutrients by quantifying the burial rate (change of storage) directly.

A first attempt at estimating the regional significance of pond $\mathrm{C}$ and nutrient sequestration rates can be made by scaling up results of this study to the total number of ponds that exist in coastal South Carolina. A recent estimate of small artificial water bodies in the eight coastal counties of South Carolina suggests there were more than 21,500 manmade ponds, representing a mix of rural, agricultural, and development-related stormwater ponds (E. Smith, unpublished data). Of this total, 9269 ponds were associated with development, and 5073 of these were associated with residential development similar to the ponds sampled in this study. These 5073 ponds have a cumulative surface area of $25.3 \mathrm{~km}^{2}$. Assuming the mean burial rates observed in this study apply, just the residential ponds alone (representing $24 \%$ of the total pond population) buried $2.0 \times 10^{9} \mathrm{~g} \mathrm{C} \mathrm{y}^{-1}$, $9.5 \times 10^{7} \mathrm{~g} \mathrm{~N} \mathrm{y}^{-1}$, and $3.7 \times 10^{7} \mathrm{~g} \mathrm{P} \mathrm{y}^{-1}$. The proliferation of ponds along this coastal zone thus represents a long-term storage of $\mathrm{C}, \mathrm{N}$, and $\mathrm{P}$ that would otherwise have been transported to coastal receiving waters. Stormwater pond sequestration values show that these ponds serve as nontrivial $\mathrm{C}$ and nutrient sinks on the local and regional scale. What remains unclear, however, is whether these rates of sequestration are ecologically significant in the context of broader coastal eutrophication and climate change. Stormwater ponds are a fixture of urban hydrology, experiencing great anthropogenic nutrient loading, yet a full understanding of how these features function in a complex hydrology is understudied. Further work is thus necessary if we are to integrate these small, but increasingly significant, ponds into a broader biogeochemical-hydrologic framework of coastal and urban systems. 


\section{ACKNOWLEDGEMENTS}

We would like to thank the home owners who graciously allowed us access to their property for sample collection. Thank you to Meryssa Piper, Susan Denham, Mary Kathrine Frame, Ray Torres, Lucas Tappa, Cameron Collins, My Phuong Le, Emily Palmer, Kelly McCabe, and Ryan Piper for the aid they provided in the field and laboratory. This work was supported by funding from the South Carolina Sea Grant Consortium, NOAA award \# NAl4OAR4170088 to EMS and CBN, as well as a grant from the Slocum-Lunz foundation, to WFS. This is contribution \#1854 of the Belle W. Baruch Institute for Marine and Coastal Sciences, University of South Carolina.

\section{OPEN ACCESS}

This article is distributed under the terms of the Creative Commons Attribution 4.0 International License (http://creativecommons.org/licenses/by/ 4.0/), which permits unrestricted use, distribution, and reproduction in any medium, provided you give appropriate credit to the original author(s) and the source, provide a link to the Creative Commons license, and indicate if changes were made.

\section{REFERENCES}

Anderson NJ, Bennion H, Lotter AF. 2014. Lake eutrophication and its implications for organic carbon sequestration in Europe. Glob Change Biol 20(9):2741-51.

Aspila K, Agemian H, Chau A. 1976. A semi-automated method for the determination of inorganic, organic and total phosphate in sediments. Analyst 101(1200):187-97.

Bastien NRP, Arthur S, McLoughlin MJ. 2012. Valuing amenity: public perceptions of sustainable drainage systems ponds. Water Environ J 26(1):19-29.

Bastviken D, Persson L, Odham G, Tranvik L. 2004. Degradation of dissolved organic matter in oxic and anoxic lake water. Limnol Oceanogr 49(1):109-16.

Benitez-Nelson CR, Madden LPN, Styles RM, Thunell RC, Astor Y. 2007. Inorganic and organic sinking particulate phosphorus fluxes across the oxic/anoxic water column of Cariaco Basin, Venezuela. Mar Chem 105(1):90-100.

Benner R. 1991. Diagenesis of belowground biomass of Spartina alterniflora in salt marsh sediments. Limnol Oceanogr 36:1358-74

Biggs J, Williams P, Whitfield M, Nicolet P, Weatherby A. 2005. 15 years of pond assessment in Britain: results and lessons learned from the work of Pond Conservation. Aquat Conserv 15(6):693-714.

Bishop CA, Struger J, Shirose LJ, Dunn L, Campbell GD. 2000. Contamination and wildlife communities in stormwater detention ponds in Guelph and the Greater Toronto Area, Ontario, 1997, and 1998. Part 2. Contamination and biological effects of contamination. Water Qual Res J Can 35(3):437434.
Boehrer B, Schultze M. 2008. Stratification of lakes. Rev Geophys. https://doi.org/10.1029/2006RG000210.

Booth DB, Roy AH, Smith B, Capps KA. 2016. Global perspectives on the urban stream syndrome. Freshw Sci 35(1):41220.

Bourbonniere RA, Meyers PA. 1996. Sedimentary geolipid records of historical changes in the watersheds and productivities of Lakes Ontario and Erie. Limnol Oceanogr 41 (2):352-9.

Brainard A, Fairchild G. 2012. Sediment characteristics and accumulation rates in constructed ponds. J Soil Water Conserv 67(5):425-32.

Brunskill G, Povoledo D, Graham B, Stainton M. 1971. Chemistry of surface sediments of sixteen lakes in the Experimental Lakes Area, northwestern Ontario. J Fish Board Can 28(2):277-94.

Cheng FY, Basu NB. 2017. Biogeochemical hotspots: role of small water bodies in landscape nutrient processing. Water Resour Res 53:5038-56.

Chiandet AS, Xenopoulos MA. 2011. Landscape controls on seston stoichiometry in urban stormwater management ponds. Freshw Biol 56(3):519-29.

Chiandet AS, Xenopoulos MA. 2016. Landscape and morphometric controls on water quality in stormwater management ponds. Urban Ecosyst 19(4):1645-63.

Clow DW, Stackpoole SM, Verdin KL, Butman DE, Zhu Z, Krabbenhoft DP, Striegl RG. 2015. Organic carbon burial in lakes and reservoirs of the conterminous United States. Environ Sci Technol 49(13):7614-22.

Cole JJ, Prairie YT, Caraco NF, McDowell WH, Tranvik LJ, Striegl RG, Melack J. 2007. Plumbing the global carbon cycle: integrating inland waters into the terrestrial carbon budget. Ecosystems 10(1):172-85.

Comings KJ, Booth DB, Horner RR. 2000. Storm water pollutant removal by two wet ponds in Bellevue, Washington. J Environ Eng 126(4):321-30.

Corbett CW, Wahl M, Porter DE, Edwards D, Moise C. 1997a. Nonpoint source runoff modeling A comparison of a forested watershed and an urban watershed on the South Carolina coast. J Exp Mar Biol Ecol 213(1):133-49.

Corbett DR, Burnett WC, Cable PH, Clark SB. 1997b. Radon tracing of groundwater input into Par Pond, Savannah River site. J Hydrol 203(1-4):209-27.

Cotti-Rausch BE, DeVoe MR. 2017. Stormwater ponds in coastal South Carolina: inventory and state of knowledge 2017. South Carolina Sea Grant Consortium. Available at www. scseagrant.org/products.

Dean WE, Gorham E. 1998. Magnitude and significance of carbon burial in lakes, reservoirs, and peatlands. Geology 26(6):535-8.

Dean WE, Gorham E, Swaine DJ. 1993. Geochemistry of surface sediments of Minnesota lakes. Geol Soc Am Spec Pap 276:115-34.

Downing J, Prairie Y, Cole J, Duarte C, Tranvik L, Striegl R, Melack J. 2006. The global abundance and size distribution of lakes, ponds, and impoundments. Limnol Oceanogr 51(5):2388-97.

Downing JA. 2010. Emerging global role of small lakes and ponds. Limnetica 29(1):0009-24.

Downing JA, Cole JJ, Middelburg JJ, Striegl RG, Duarte CM, Kortelainen P and others 2008. Sediment organic carbon burial in agriculturally eutrophic impoundments over the last 
century. Global Biogeochem Cycles. https://doi.org/10.1029/ 2006 GB002854.

Eglinton G, Hamilton R. 1967. Leaf epicuticular waxes. Science 156:1322-35.

Ficken KJ, Li B, Swain DL, Eglinton G. 2000. An $n$-alkane proxy for the sedimentary input of submerged/floating freshwater aquatic macrophytes. Org Geochem 31(7-8):745-9.

Fissore C, Baker L, Hobbie S, King J, McFadden J, Nelson K, Jakobsdottir I. 2011 . Carbon, nitrogen, and phosphorus fluxes in household ecosystems in the Minneapolis-Saint Paul, Minnesota, urban region. Ecol Appl 21(3):619-39.

Fletcher T, Andrieu H, Hamel P. 2013. Understanding, management and modelling of urban hydrology and its consequences for receiving waters: a state of the art. Adv Water Resour 51:261-79.

Gälman V, Rydberg J, de-Luna SS, Bindler R, Renberg I. 2008. Carbon and nitrogen loss rates during aging of lake sediment: changes over 27 years studied in varved lake sediment. Limnol Oceanogr 53(3):1076-82.

Gold A, Thompson S, Piehler M. 2017. Coastal stormwater wet pond sediment nitrogen dynamics. Sci Total Environ 609:67281 .

Gorham E, Lund JW, Sanger JE, Dean WE. 1974. Some relationships between algal standing crop, water chemistry, and sediment chemistry in the English Lakes. Limnol Oceanogr 19:601-17.

Grimm NB, Foster D, Groffman P, Grove JM, Hopkinson CS, Nadelhoffer KJ, Peters DPC. 2008. The changing landscape: ecosystem responses to urbanization and pollution across climatic and societal gradients. Front Ecol Environ 6(5):264-72.

Gudasz C, Bastviken D, Steger K, Premke K, Sobek S, Tranvik LJ. 2010. Temperature-controlled organic carbon mineralization in lake sediments. Nature 466(7305):478-81.

Harrison JA, Maranger RJ, Alexander RB, Giblin AE, Jacinthe PA, Mayorga E, Wollheim WM. 2009. The regional and global significance of nitrogen removal in lakes and reservoirs. Biogeochemistry 93(1):143-57.

Höhener P, Gächter R. 1993. Prediction of dissolved inorganic nitrogen (DIN) concentrations in deep, seasonally stratified lakes based on rates of DIN input and $\mathrm{N}$ removal processes. Aquat Sci Res Across Bound 55(2):112-31.

Holland AF, Sanger DM, Gawle CP, Lerberg SB, Santiago MS, Riekerk GH, Scott GI. 2004. Linkages between tidal creek ecosystems and the landscape and demographic attributes of their watersheds. J Exp Mar Biol Ecol 298(2):151-78.

Hopkinson CS, Fry B, Nolin AL. 1997. Stoichiometry of dissolved organic matter dynamics on the continental shelf of the northeastern U.S.A. Cont Shelf Res 17(5):473-89.

Jacobson CR. 2011. Identification and quantification of the hydrological impacts of imperviousness in urban catchments: a review. J Environ Manage 92(6):1438-48.

Jacoby J, Lynch D, Welch E, Perkins M. 1982. Internal phosphorus loading in a shallow eutrophic lake. Water Res 16(6):911-19.

Kaye JP, Groffman PM, Grimm NB, Baker LA, Pouyat RV. 2006. A distinct urban biogeochemistry? Trends Ecol Evol 21(4):192-9.

Klump JV, Edgington DN, Sager PE, Robertson DM. 1997. Sedimentary phosphorus cycling and a phosphorus mass balance for the Green Bay (Lake Michigan) ecosystem. Can J Fish Aquat Sci 54(1):10-26.
Knoll LB, Vanni MJ, Renwick WH, Kollie S. 2014. Burial rates and stoichiometry of sedimentary carbon, nitrogen and phosphorus in Midwestern US reservoirs. Freshw Biol 59(11):2342-53.

Kopáček J, Borovec J, Hejzlar J, Ulrich K-U, Norton SA, Amirbahman A. 2005. Aluminum control of phosphorus sorption by lake sediments. Environ Sci Technol 39(22):8784-9.

Lewitus AJ, Brock LM, Burke MK, DeMattio KA, Wilde SB. 2008. Lagoonal stormwater detention ponds as promoters of harmful algal blooms and eutrophication along the South Carolina coast. Harmful Algae 8(1):60-5.

Lu Y, Meyers PA. 2009. Sediment lipid biomarkers as recorders of the contamination and cultural eutrophication of Lake Erie, 1909-2003. Org Geochem 40(8):912-21.

Mackay EB, Jones ID, Folkard AM, Barker P. 2012. Contribution of sediment focussing to heterogeneity of organic carbon and phosphorus burial in small lakes. Freshw Biol 57(2):290-304.

Mallin MA, Ensign SH, Wheeler TL, Mayes DB. 2002. Pollutant removal efficacy of three wet detention ponds. J Environ Qual $31(2): 654$.

Mengis M, Gächter R, Wehrli B, Bernasconi S. 1997. Nitrogen elimination in two deep eutrophic lakes. Limnol Oceanogr 42(7):1530-43.

Meyers P. 2003. Applications of organic geochemistry to paleolimnological reconstructions: a summary of examples from the Laurentian Great Lakes. Org Geochem 34:261-89.

Meyers PA. 1997. Organic geochemical proxies of paleoceanographic, paleolimnologic, and paleoclimatic processes. Org Geochem 27(5-6):213-50.

Meyers PA, Ishiwatari R. 1993. Lacustrine organic geochemistry-an overview of indicators of organic matter sources and diagenesis in lake sediments. Org Geochem 20(7):867-900.

Moore TL, Hunt WF. 2012. Ecosystem service provision by stormwater wetlands and ponds-a means for evaluation? Water Res 46(20):6811-23.

Mulholland PJ, Elwood JW. 1982. The role of lake and reservoir sediments as sinks in the perturbed global carbon cycle. Tellus 34(5):490-9.

Nagy R, Lockaby BG, Helms B, Kalin L, Stoeckel D. 2011. Water resources and land use and cover in a humid region: the southeastern United States. J Environ Qual 40(3):867-78.

Nürnberg GK. 1988. Prediction of phosphorus release rates from total and reductant-soluble phosphorus in anoxic lake sediments. Can J Fish Aquat Sci 45(3):453-62.

O'Driscoll M, Clinton S, Jefferson A, Manda A, McMillan S. 2010. Urbanization effects on watershed hydrology and in-stream processes in the southern United States. Water 2(3):605-48.

Reed ML, DiTullio GR, Kacenas SE, Greenfield DI. 2015. Effects of nitrogen and dissolved organic carbon on microplankton abundances in four coastal South Carolina (USA) systems. Aquat Microb Ecol 76(1):1-14.

Saunders DL, Kalff J. 2001. Hydrobiologia 443(1/3):205-12.

SCDHEC. 2005. Storm water management BMP handbook. Columbia: SCDHEC.

Serrano L, DeLorenzo ME. 2008. Water quality and restoration in a coastal subdivision stormwater pond. J Environ Manage $88(1): 43-52$.

Siegel A, Cotti-Rausch B, Greenfield DI, Pinckney JL. 2011. Nutrient controls of planktonic cyanobacteria biomass in coastal stormwater detention ponds. Mar Ecol Prog Ser 434:15-27. 
Silliman JE, Meyers PA, Bourbonniere RA. 1996. Record of postglacial organic matter delivery and burial in sediments of Lake Ontario. Org Geochem 24(4):463-72.

Smith SV, Renwick WH, Bartley JD, Buddemeier RW. 2002. Distribution and significance of small, artificial water bodies across the United States landscape. Sci Total Environ 299(13):21-36.

Søndergaard M, Jensen JP, Jeppesen E. 2003. Role of sediment and internal loading of phosphorus in shallow lakes. Hydrobiologia 506(1):135-45.

Søndergaard M, Jeppesen E, Jensen JP. 2005. Pond or lake: does it make any difference? Arch Hydrobiol 162(2):143-65.

Song K, Xenopoulos MA, Buttle JM, Marsalek J, Wagner ND, Pick FR, Frost PC. 2013. Thermal stratification patterns in urban ponds and their relationships with vertical nutrient gradients. J Environ Manage 127:317-23.

Stanley DW. 1996. Pollutant removal by a stormwater dry detention pond. Water Environ Res 68(6):1076-83.

Tafuri AN, Field R. 2012. Treatability aspects of urban stormwater stressors. Front Environ Sci Eng 6(5):631-7.

Tixier G, Lafont M, Grapentine L, Rochfort Q, Marsalek J. 2011. Ecological risk assessment of urban stormwater ponds: literature review and proposal of a new conceptual approach providing ecological quality goals and the associated bioassessment tools. Ecol Ind 11(6):1497-506.

Tranvik LJ, Downing JA, Cotner JB, Loiselle SA, Striegl RG, Ballatore TJ et al. 2009. Lakes and reservoirs as regulators of carbon cycling and climate. Limnol Oceanogr 54(6 part 2):2298-314.

van Dongen BE, Semiletov I, Weijers JWH, Gustafsson Ö. 2008. Contrasting lipid biomarker composition of terrestrial organic matter exported from across the Eurasian Arctic by the five great Russian Arctic rivers. Glob Biogeochem Cycles. https:// doi.org/10.1029/2007GB002974.

Verstraeten G, Poesen J. 2000. Estimating trap efficiency of small reservoirs and ponds: methods and implications for the assessment of sediment yield. Prog Phys Geogr 24(2):219-51.

Verstraeten G, Poesen J. 2002. Regional scale variability in sediment and nutrient delivery from small agricultural watersheds. J Environ Qual 31(3):870-9.

Vitousek PM, Mooney HA, Lubchenco J, Melillo JM. 1997. Human domination of Earth's ecosystems. Science 277(5325):494-9.

Walsh CJ, Fletcher TD, Burns MJ. 2012. Urban stormwater runoff: a new class of environmental flow problem. PLoS ONE 7(9):e45814.

Walsh CJ, Roy AH, Feminella JW, Cottingham PD, Groffman PM, Morgan RPII. 2005. The urban stream syndrome: current knowledge and the search for a cure. J N Am Benthol Soc 24(3):706-23.

Weinstein JE, Crawford KD, Garner TR. 2010. Polycyclic aromatic hydrocarbon contamination in stormwater detention pond sediments in coastal South Carolina. Environ Monit Assess 162(1):21-35.

Williams CJ, Frost PC, Xenopoulos MA. 2013. Beyond best management practices: pelagic biogeochemical dynamics in urban stormwater ponds. Ecol Appl 23(6):1384-95.

Wu JS, Holman RE, Dorney JR. 1996. Systematic evaluation of pollutant removal by urban wet detention ponds. J Environ Eng 122(11):983-8.

Zehnder AJB, Svensson BH. 1986. Life without oxygen: what can and what cannot? Experientia 42(11-12):1197-205. 